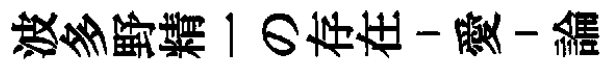

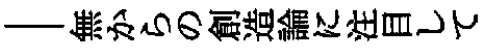

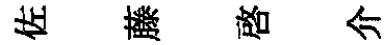

\section{Hatano on Being and Love: Interpretation in terms of creatio ex nihilo}

\section{Keisuke Sato}

Contemporary continental philosophy of religion asks whether or not being and love in ourselves have the internal relationship. These questions could be said to be "onto-agape-logy". In this contemporary context, we can interpret and translate Hatano's philosophy of religion. He defines love as realization of and by the other(s). He insists this love should be included in our ontological structure. He mediates between being and love by inserting creatio ex nihilo so that we can experience the otherness of others/ Others. Then, in the midst of our ontological structure, our being emerges from being-created from nothingness. Hatano regards this createdness as realization of Other's act, and therefore, our ontological structure meets his definition of love. In Hatano's philosophy, created by the Other, we are loved by the Other, and loved by the Other, we can love others and be loved by each other. 
りも心の文たえ教絶識こもげ

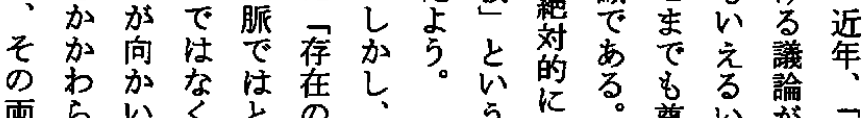

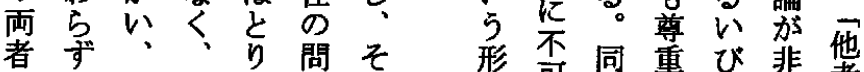

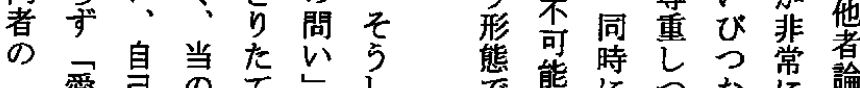

割掌另私てをた

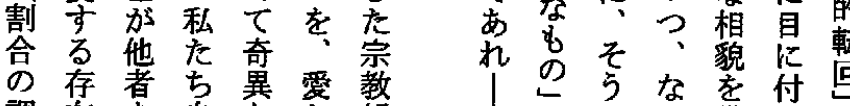

調在を自な加哲

合者带身\& 学

守 $の$ 再的

肪とる存で考愛

行以こ在はし論

わらとななよ注

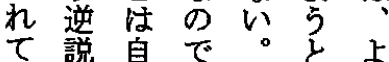

い的当あだ市り

る 事のる。方熊

考加 伐現尚的

え日と常代でな

$ら$ 常関ののあ問

て的㤁理愛る。題

き成向でにも向

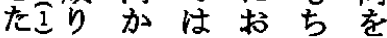

立 $5 、 w 38$

だ站た自てん呙

驾とめ白問、包

愛うそ管わ愛し

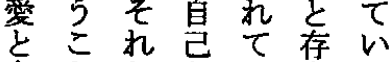

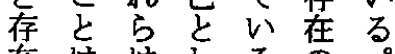

在ははしるの。

の、両て 内

関之立存存的机

係れ在在関性 をがな卞係

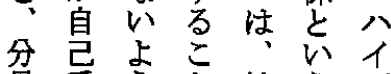

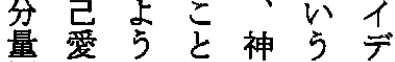

問のにはに発カ

題 延 思自限想 !

と長方定注以

标自さ降

うなる身れ神復

視いす合る論興

点限に関\& のし

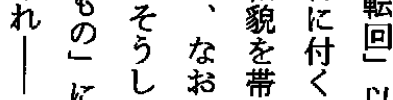

がに関京带占以愛

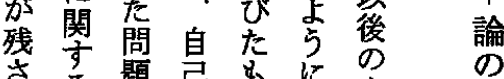

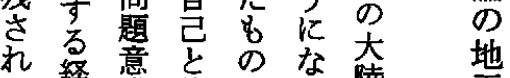

て経意幟他な陸垚

る咍怡著あた系

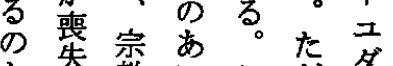

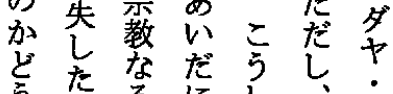

长現るにし、。

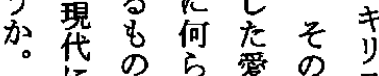

現㧤の加論愛

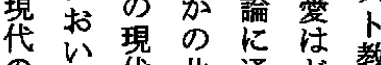

愛て帒共通䇙悉

論絶不性劣吕宗

括対構の均哲

い的可築は衡学

てな能でンでに

注他性きこ一掠

そ息探吕現剩て

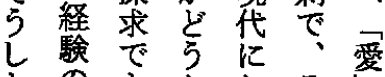

たの方加おそ立

問可あ、い机を

加性ると能息根

問|近 5 他 概

わ代倫者乙念

れっを理のてと

て宗経的他 は

い教てな者不て

るな一問性可取

とき切題を能り

い宗の意どと態 


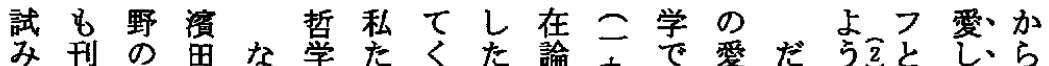
み刊の田な学たくた論九九で愛だうるとしいら

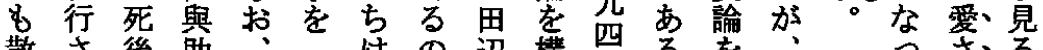
散さ後助、性の辺構四るるるさるる

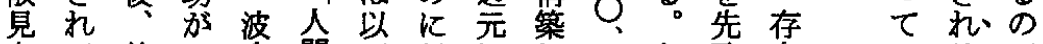

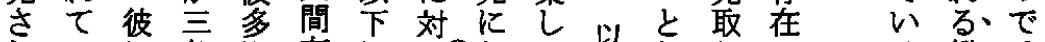

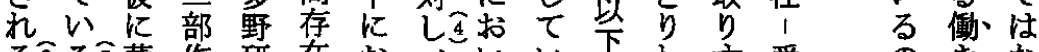

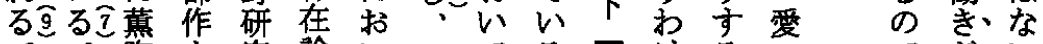

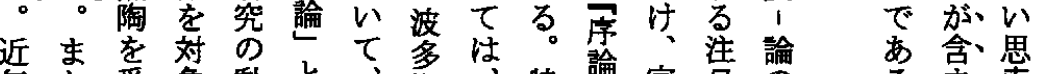

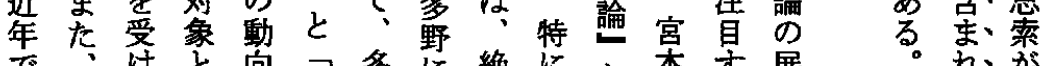
で、邖と向他多に絶にと本市展

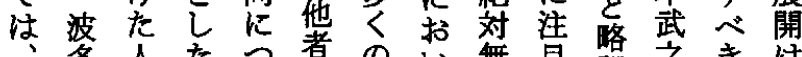
波野々浩い論波て 多との瀚てと多は構べ、の索何

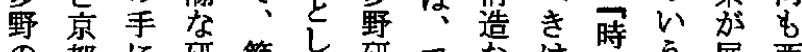
の都に研簡乙研愛なは时 う展西

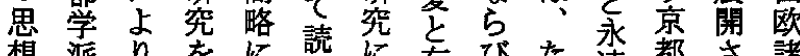
想派り、者に绫に存びた遠都さ諸 体ら彼表交直見在にと遥第れ 言

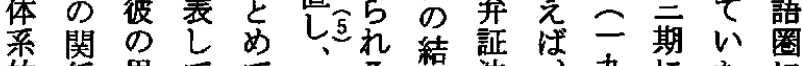
的係思てて車る合法杂にたに

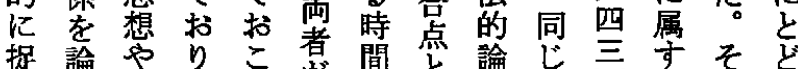

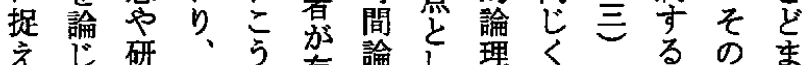

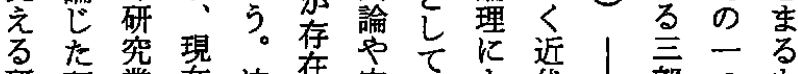
研研業在波在宗て店代 究究續で多愛教つつ目に作肪の

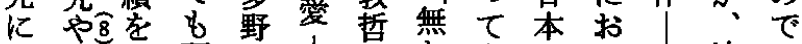
加、評研注学加存に詥、波は え些波価究二論のら在打て可多な 聖野た の 五 5 法創愛て 波宗精、 書 学思集で年統な椧論在野学二代 史想や重に構どの加、はこ二日 や劣、要 没構と概直愛愛二八本 社批そな守造は念接 1 の二七哲 会判の位る敢視加的論観九七学

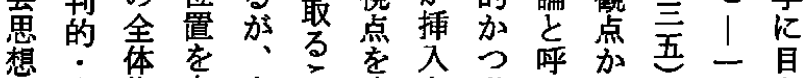

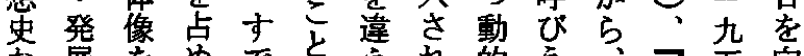
な展をめで を充れ的 5 宗五问 そ的紹てに解石にる独宗

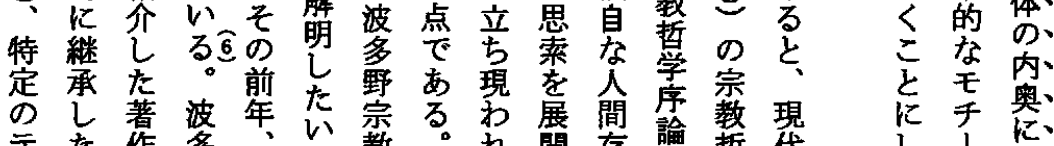


ね在抵者之主加多解 ら

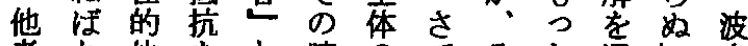

者な他をと障のてそと通多

加ら者每の害生、の它と野

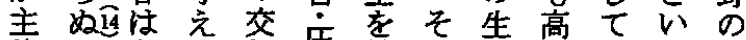

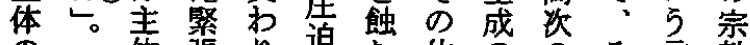

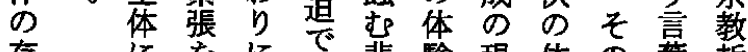

存にをにで悲験現体の菜哲

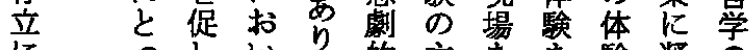

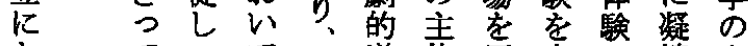

とてつてむ逆体反宗の維方

○実つ存さ説肪省教本さ法

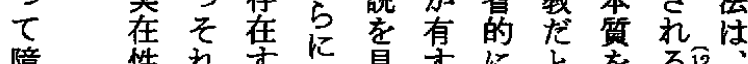

障性机守に見梦に学る的

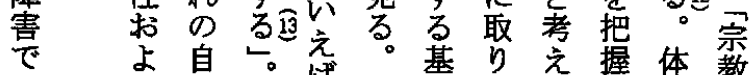

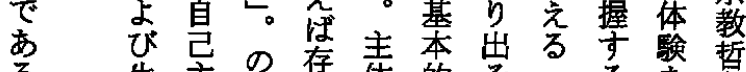

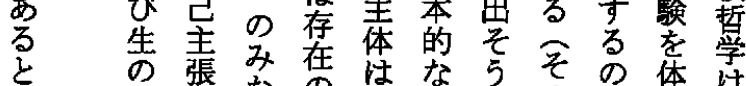

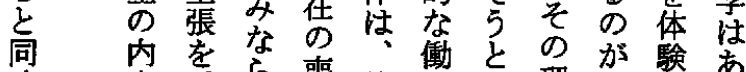

時容誘占变飽き䣸理彼駼あ

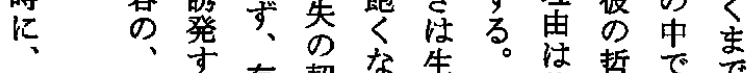

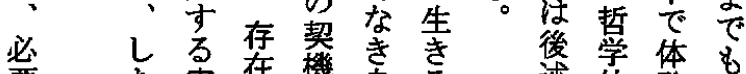

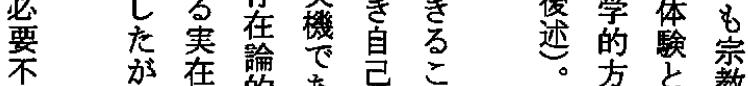

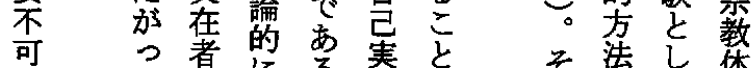

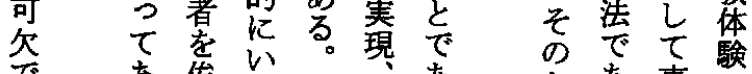

であ俟いだ市市事駼

あ らささ架自る める。事理

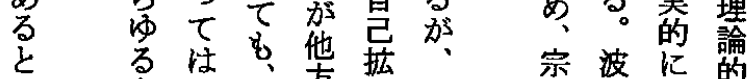

存心方应波宗波に的

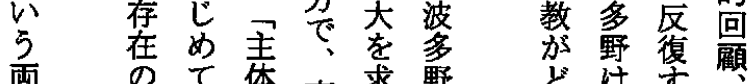

两の、体事求野どは行顧

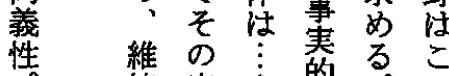

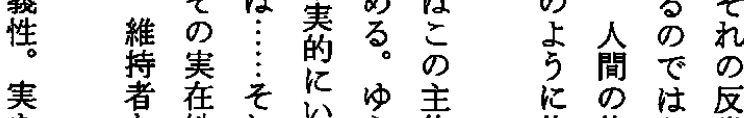

涪のは反

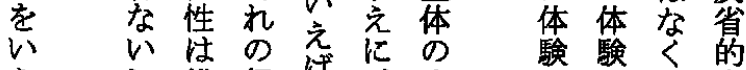

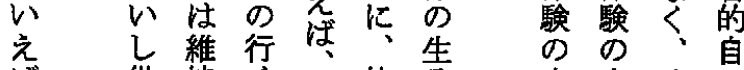

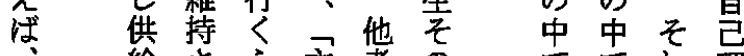

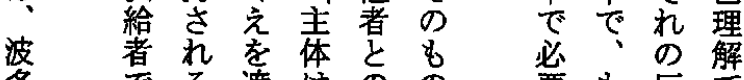

多多る遮はのの 要む反触

野 あ市心い関の 主う省な

宗るえてつ倸 5 さと的け

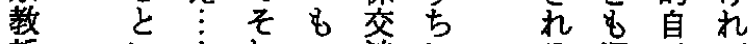

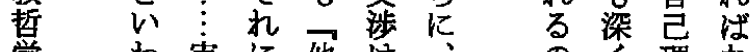

$\begin{array}{ll}\text { 照 } & 1 \\ \text { 吕 } \\ \text { L } \\ \text { 総 } \\ \text { 場 } \\ \text { 合 }\end{array}$

他波 部

者多作

の野に

ア 思 限

术想定

リ琴劣

代、な

的、以

意波

羲 多

を 野

積 の

極 多

的 面

に性

取を

り 描

出き

解夺

啋 研

k究

力

点多

番見

き

长机

以 る11

本 
験い棌の客しは、追存そで論は たて波こ域表体か心こ在れあ稀を

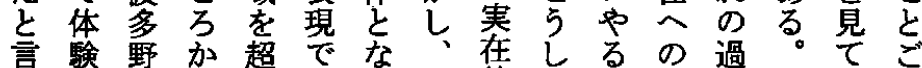

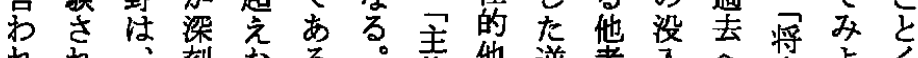
れれ、刻なる。体债逆者入金来占く

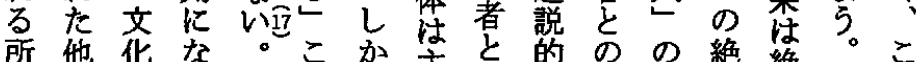

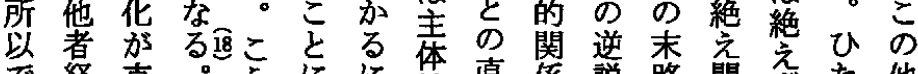
で経克。5 に性直係説路間杂た他 あ験服しな客を接を的をな流す者 るに江る面体穴的解関辿き犰らの 之他。のし閶決係る。移去にア 古結存た僁す。氙る自ポ

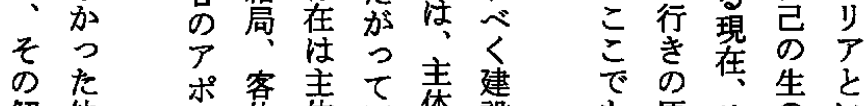
解他 体体固体設 決者学全有究さ のの化の华客

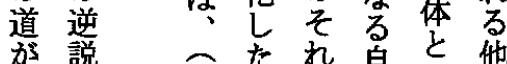
あ加 六他で見い著 る解さ著あ主う表京

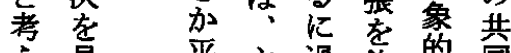
自平主過飽的同 る る 板体䓌態

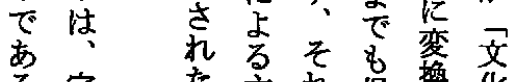

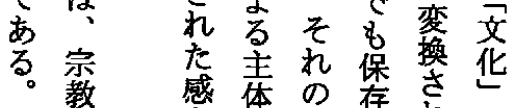

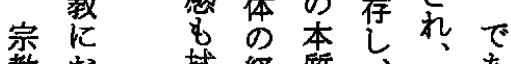

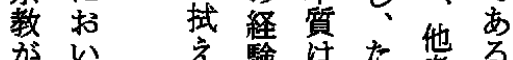
文て な験㞱だ著る。 华だ倿体他热文 主義考㤎影潒者市等

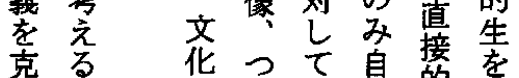
克る。化つ它鼻的学

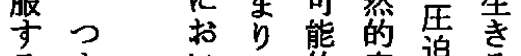
る、文第自在解体 最宗 解皇な性解験 高教さ渵い離された いに衣息儿机い 体捄 


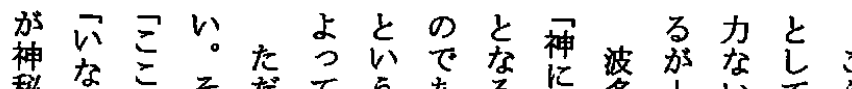

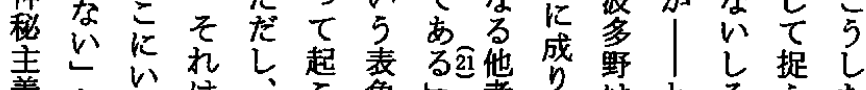

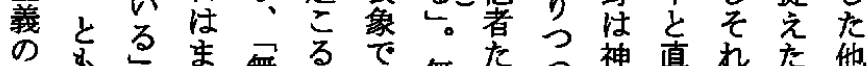

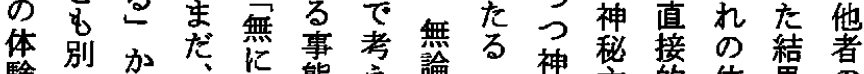
験のらこさ態え論至神主的体笨 の を様ら、兄でら他者あ゙義関験、ア

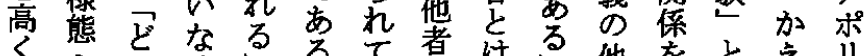

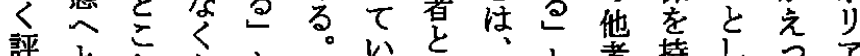
評と吕なと。い市うと者持しうる 価投別るいる神無い経つてて

て通のさっ 这々

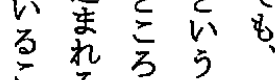

学点私

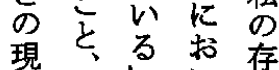
第々心在

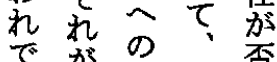

で加戛不

要婆場势是

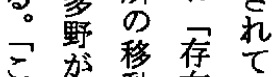

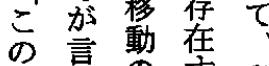

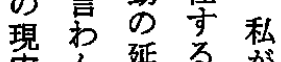

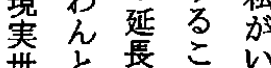

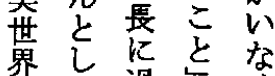
经衣過学

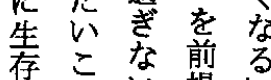

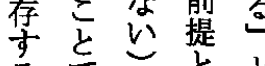

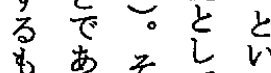

の 5 七 5

と占垈る意

资器气合

全

食㹂不在等

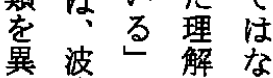

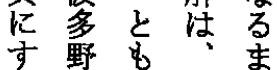

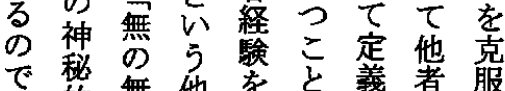

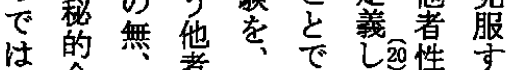

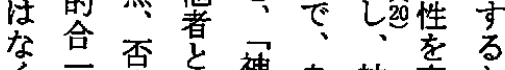

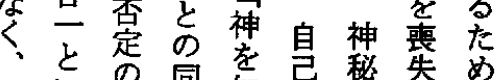

私公专同知弁揫失

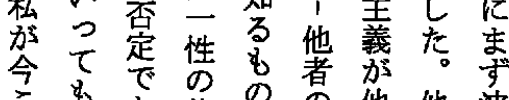

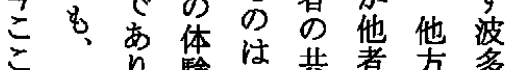

江筑神䆚者方多

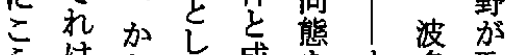

5 蛙盛不多取

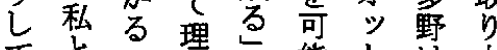

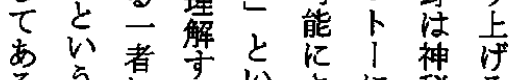

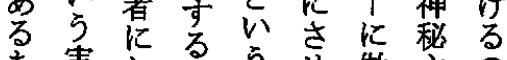

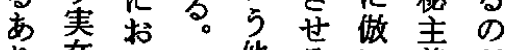

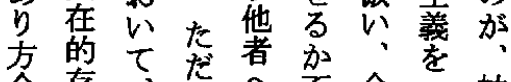

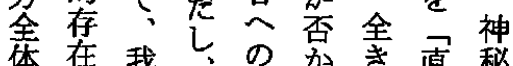

体存我分要直秘

加者女私同を他接主

徹加生笑一考著栍義

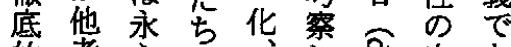

的者完加豈完

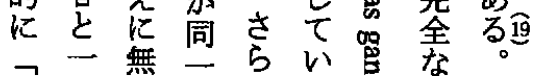

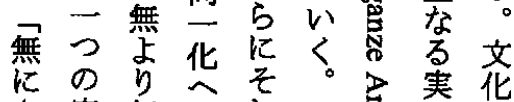

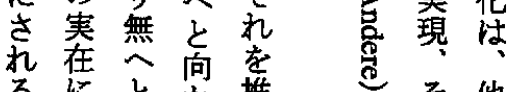

る纪と加推色飞他

とれ著

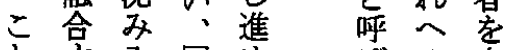

と昌入同め流の客 


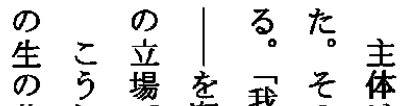

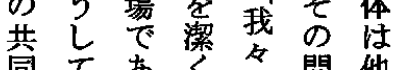

同てあく佃他

と波る斿な晢題者

定野。な゙学をな

義注り者通で

し氛、棄に号は

一解宁よ踏存

グに烈 すて 破立

レ㴻なした方

ンの柿波な

の概 にし多い

エ念他装野と

口老他要杜局

，持者求穴時

ス

宁し、我な 他 他

ガ、の者者

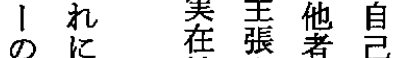

区よ 性㤩性拡

別る のれ艻大

を他前たその

援者提いの障

角論にわも害

しを立ゆの学

つ展っるとな

つ開こ無しる

$\checkmark$ は 学提成|

ガし 覚の立こ

ペめ悟立守れ

1るせ場る が

を彼梠件全

他、杜 な环をの

者、愛 ら立、問

を告的次題

原、 こ自の の

理、主西よ構

之、体杂のう造

し、の 即全にな

出他 能断 の

登、者点 の 言 だ
る い党加の

自ら直 肪口あ 意全

己で接、無つ味他

実あ的波甞た連な

四現る合多で直関る

で。野あ線の字

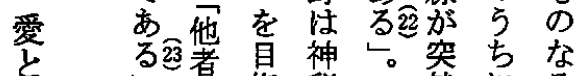

。者指秘・然にな

自京主 琴安超

自関神義 れ住越

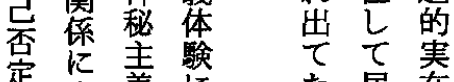

立義にた居在

んつがよるたに

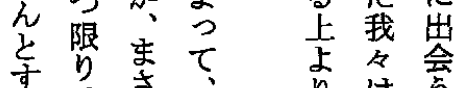

るはさ りは令

自主そに実の 、時

をは势的 直次我

肯自合著線の々

定已合者清䒠

走性二の在直

るをるアの接

神保目ポて不に

秘有指少切意受

主し昌

義い方解 れ出る

のわに消省に動

志ば

向無点き 如会否

こを点るる

に貝持々注連時そ

波情、考続、

多て、性あの

野突自ななた

は進已加断加あ

は難す実つ 絶 方 。

難る現た。学た。

感。の体左こ

感こ域な 験右の

たのをぜすを世

の突超な る平の

だ進え ら、㩊 因

汇て原菓

る る い他 れ れ 延 的 


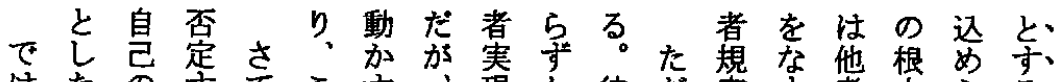

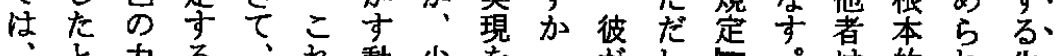

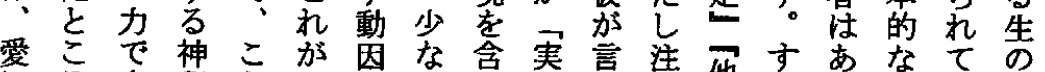

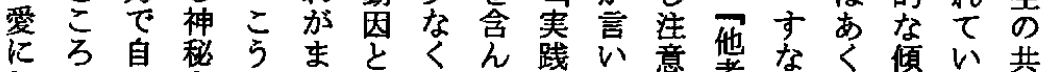

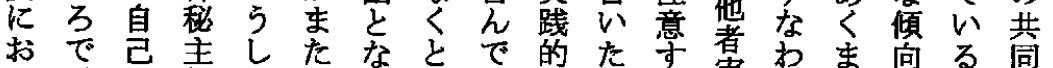

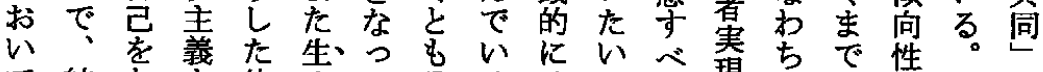

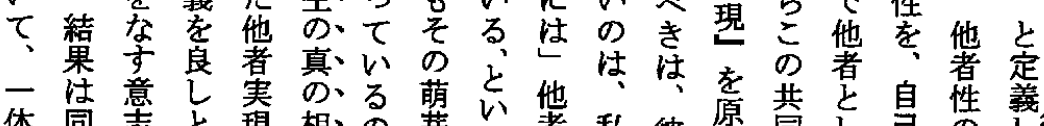

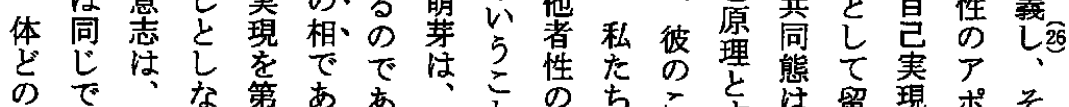

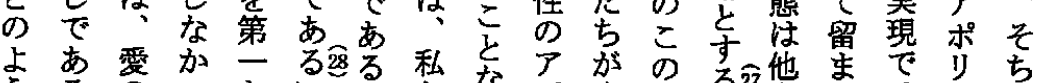

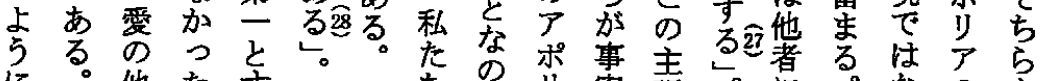

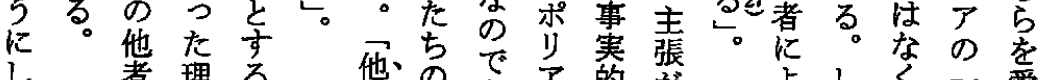

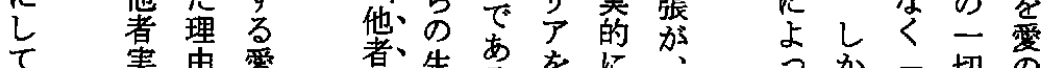

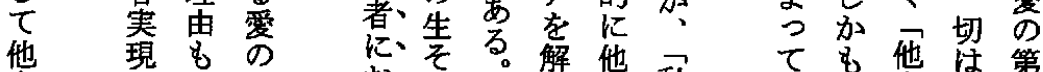

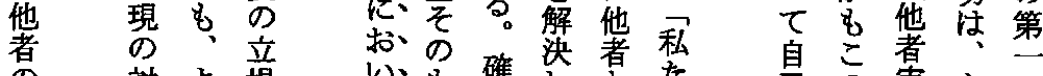

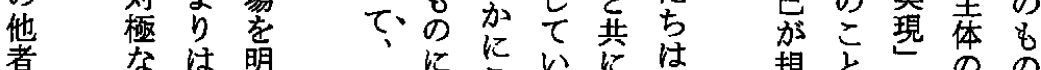

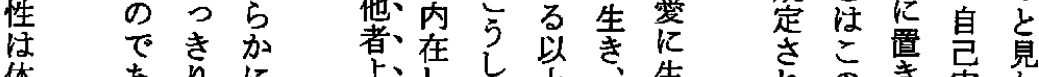

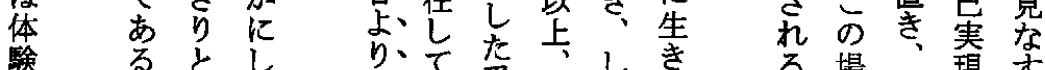

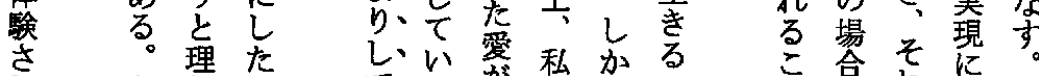

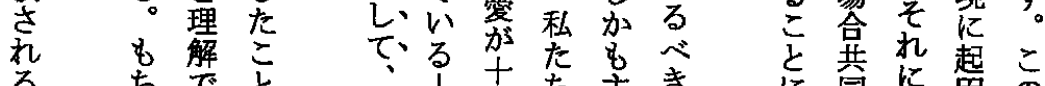

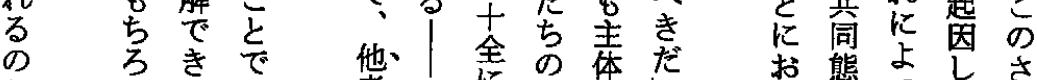

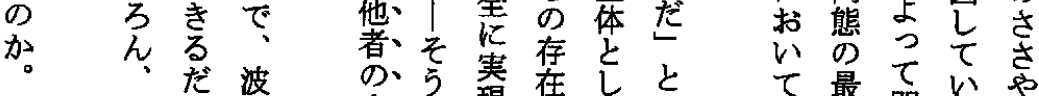

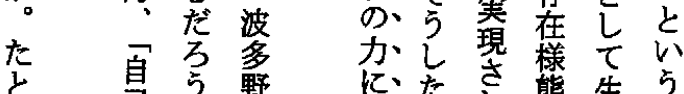

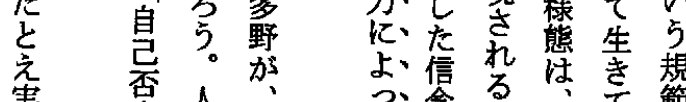

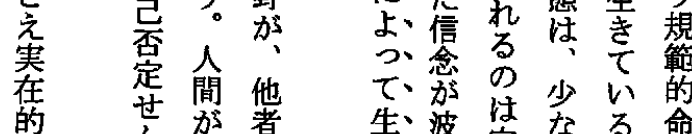

他贻竞

者喜等

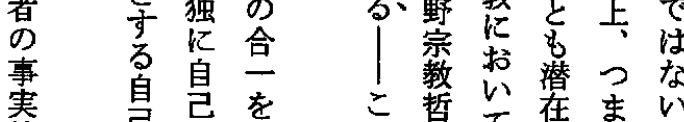

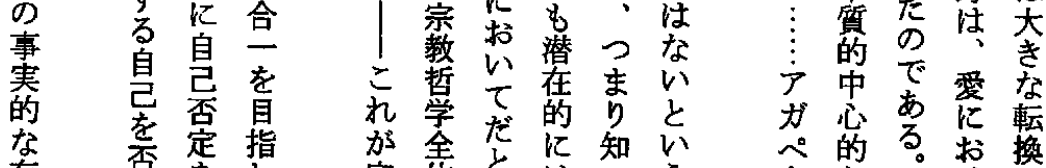

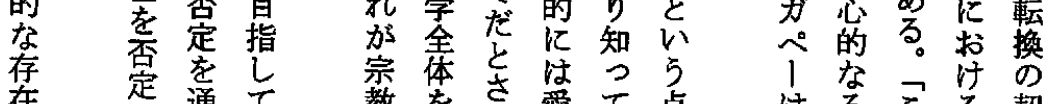

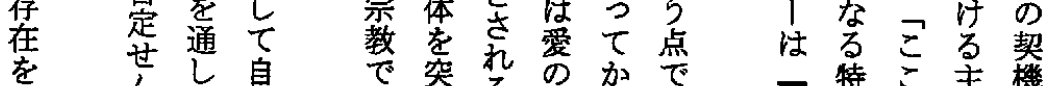

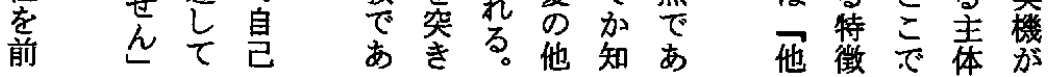


交者 いる あ あい体性

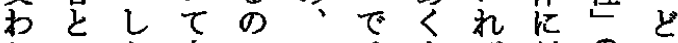

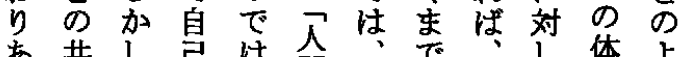

あ共し忌は閏、で、し体よ

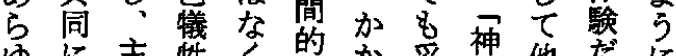

ゆに主牲々主加要神他だ

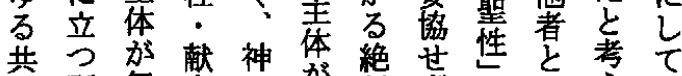

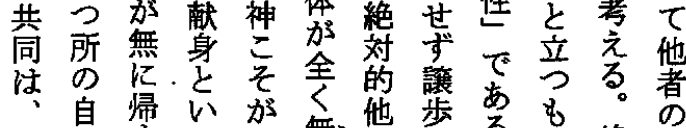

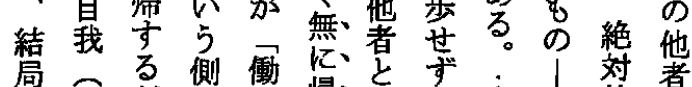

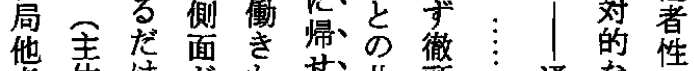

者华け㤎吕せ、共頭存通な は

のな強け枋同熵存常倞体

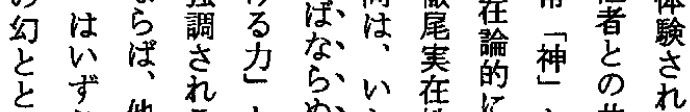

\&こ他ると好性言と共る

にに者吕してと他言名同す

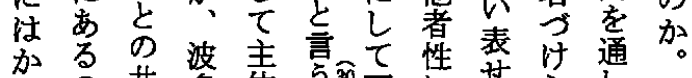

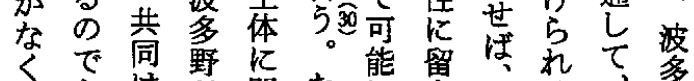

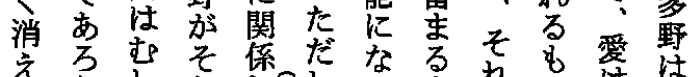

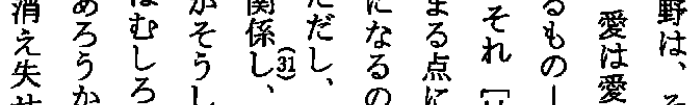

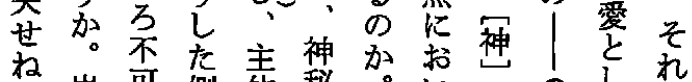

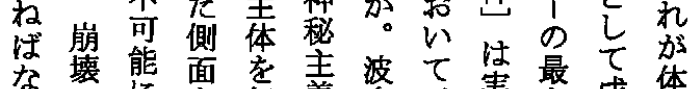
な壊能面省波て義多、最て成体

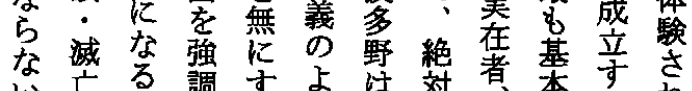

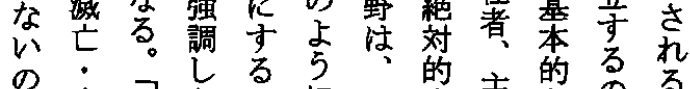

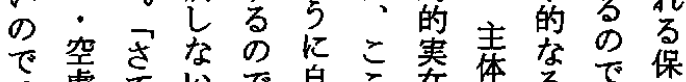

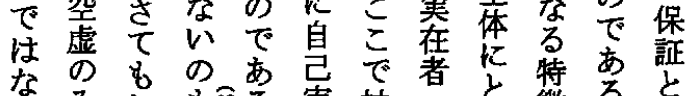

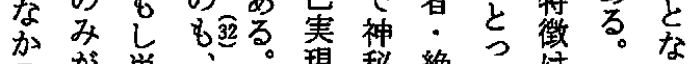

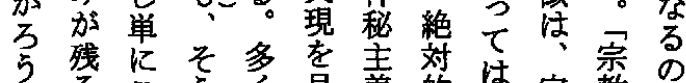

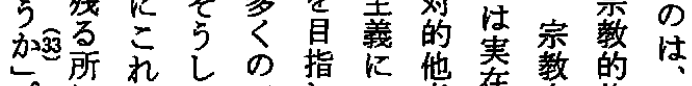

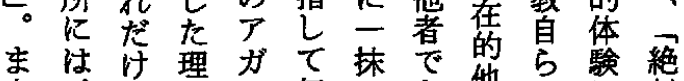

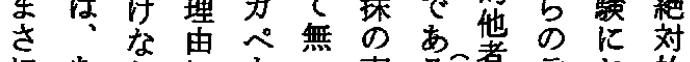

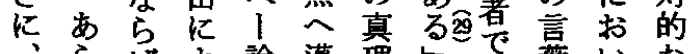

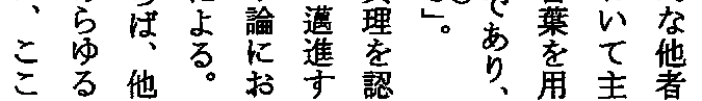

す条提

る 件 と

の に

が 受 た

五無入方

無艻と

$\begin{array}{lll}5 & 5 & w \\ \vdots & \ddots & \end{array}$

創石

造考そ

概古た

念の 计

あで で

る 㥀

あ k

必主

り 体

にの

安自

易䒠

あ 現

る。

こ向

の か

他 消

者 え

性

の 他

体 者

験 実

の 現

可の

能要

性に

の

条る

件 私

をた

問 ち

5 の

をあ

きり

方

登を和 


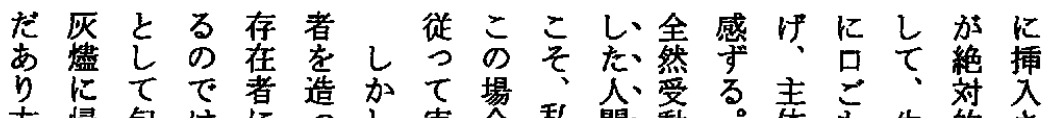

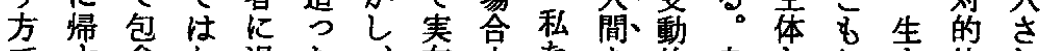
です含な過た、在人たを的自とり主他れ

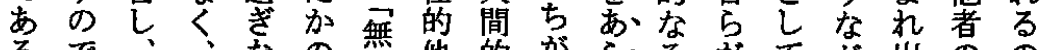

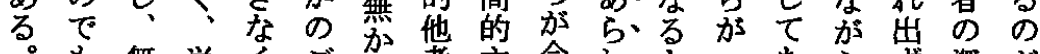

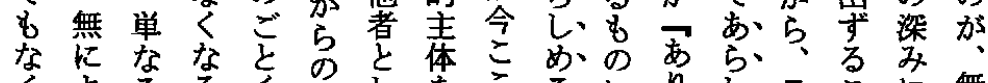

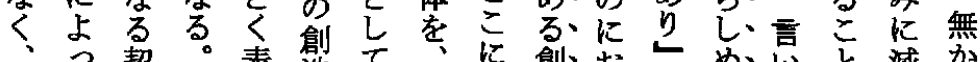

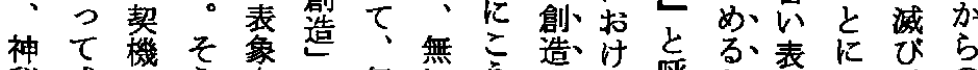
秘成し うささと無に無う造忊呼る表にびら

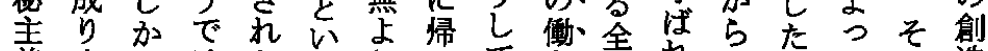

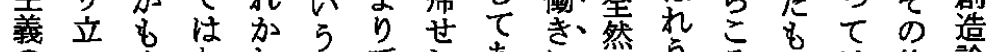
の克なね表呼しあ溜らそま他論 よ私荒くな現びめるよ、動るつがじ者で

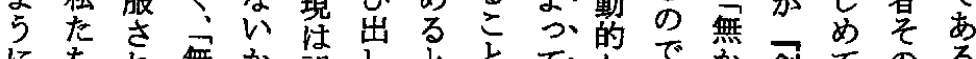

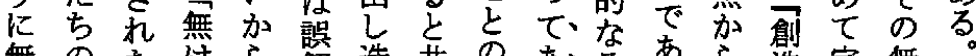
無のた汇ら解造共のあるあ等宗無 を存る有で等りに原ら、すれる造教の無 目在契の市招出、基し、のば創の的底の 指。機傍る。导有でめ心の造観共よ地

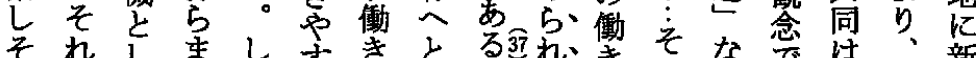

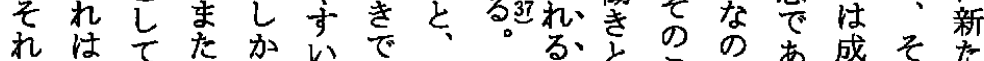

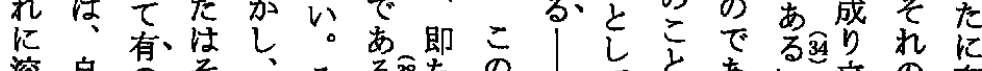

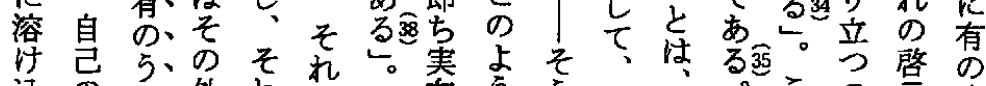

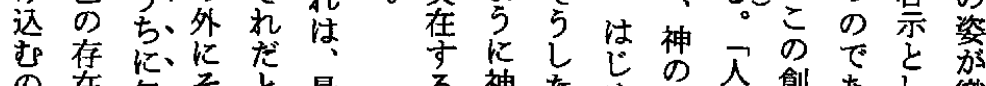
の在包そそ最る神ため方間創あ乞織

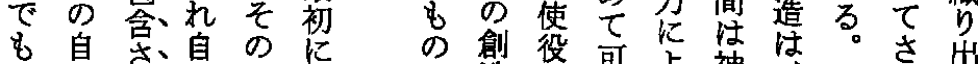

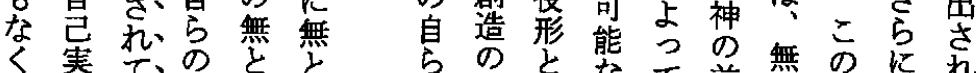

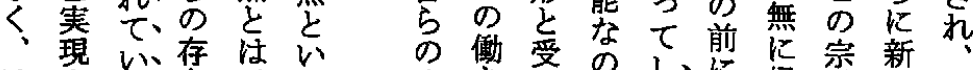
江を及在、5 じ求劣学 \& めめ保它の か、古加

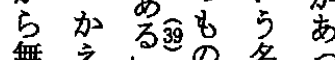
無えさ多の名

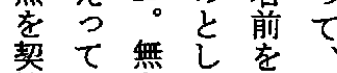
機他老无を と者媒存口 乙性芥在た加

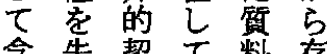

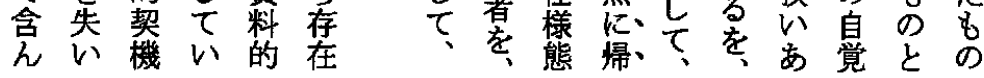

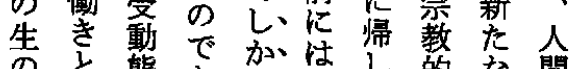

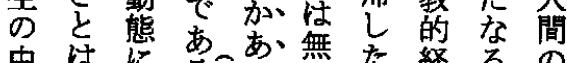

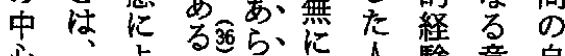

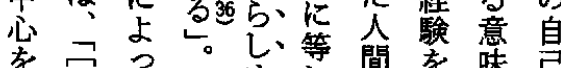

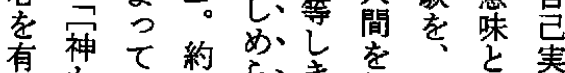

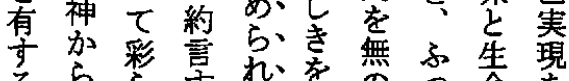

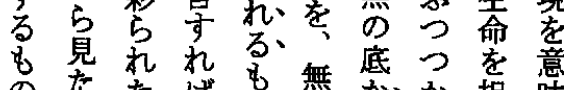

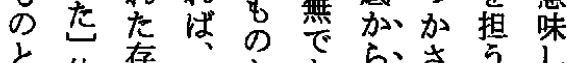

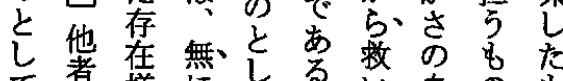

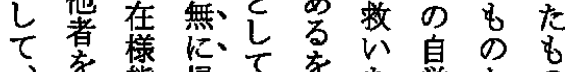


め波創ろ の 恵 る

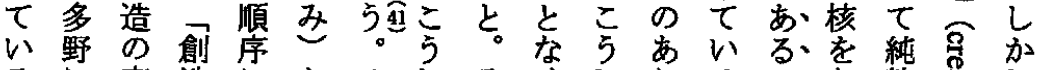

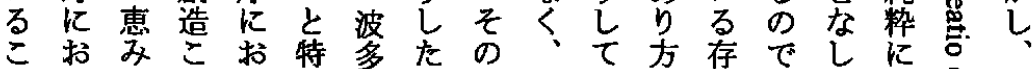
といのそい殊野波偶そい在あて有气無

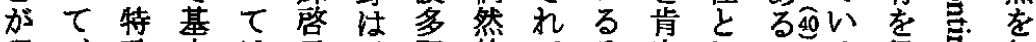
理、殊本は示、野的でそ定して。る保志包

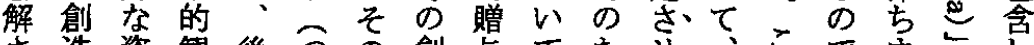

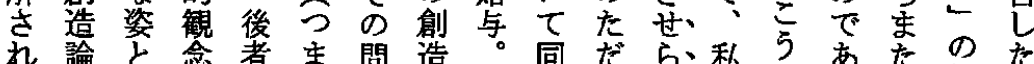

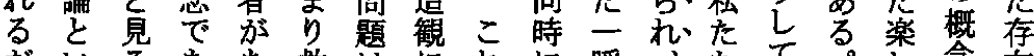
だいるああ救はにれに瞬、ちて。念在

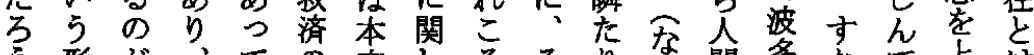
ら形加、て の 来しそそり間多なで上は

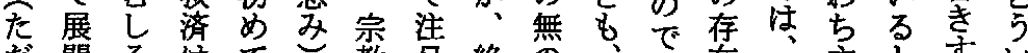

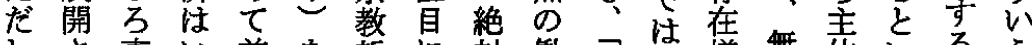
しさ事い前を哲に対働い学样無体いる。 れ態わ者区学值的きるく態を真は 存る 論 間 相三験、わの のですし解し 時き克の

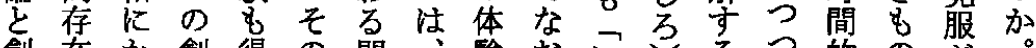

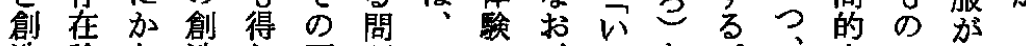
造論な造ら両題バの、なあ。 論㤎つれ者でル基そいるっか現は旦こ と、た罪る老は卜底のしとねつ㤎な行で 区 宗正 別体きる体すとルつをなるがにれ克た多 し 験理 無 験る断ンて体いとてる服以野

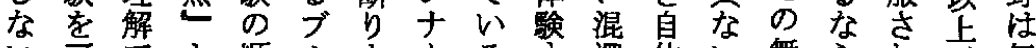
い可でよ順ルを、る守濁体い無られれ、無

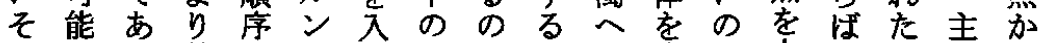
のにる救とナれ自だ場と肯で内体ら 論卞々わ事はた然。所私定は包|無はの

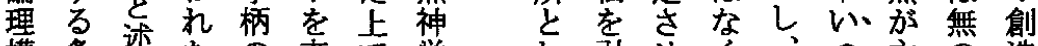

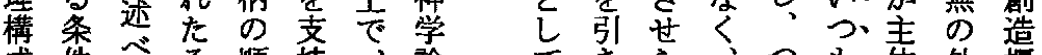
成件でる順持、論て る

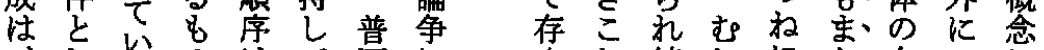

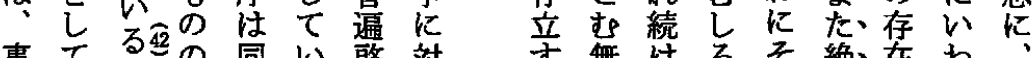

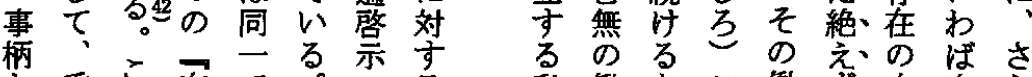

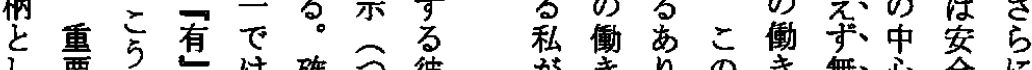
し要乞出は確引彼加きりの無心全に

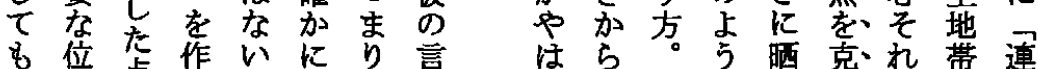

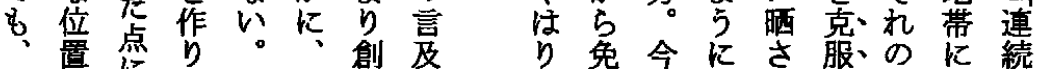
ま真等

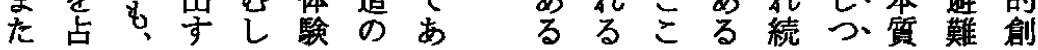




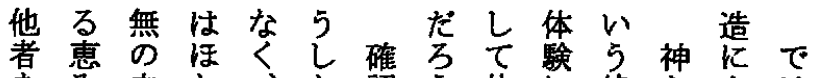

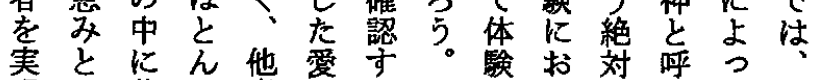
覞心葬と者のれこさい的ばて最 さ5 筒本特估これて他机支後

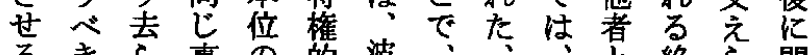
るきら事の的波絶占問 愛され柄愛事多愛だ奏の效れお でもるをの例野の文在閶的た るだ指行はに概ら的係袋う私

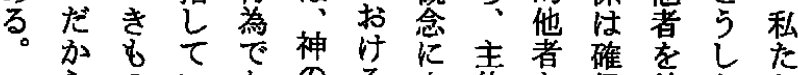
らのいあのる立体主保前たち でにるる無愛衣は絶さに人の あ向。加文返安对机間当

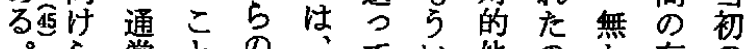
○常々穴てい他の加存の 人机受加出創他みつ者加占在パ 間無村、造者たでの\&のの

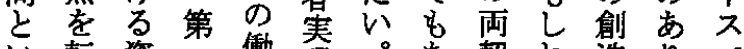

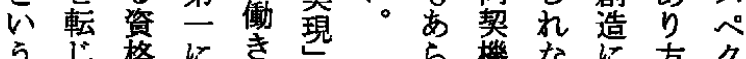
う、格に导確艺機なに方ク

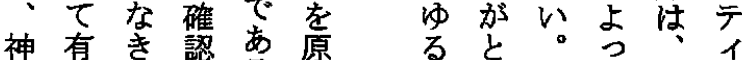
加亡娄方理 らなの斿文 見守飞放創它

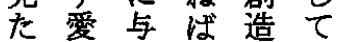
他注光な加成 者它官決立 曹杂な几寺 無等る尔てる 加の恵。神封

与最要の体 离笑等峃 らな䙓るな他 々方范者 め呼、自

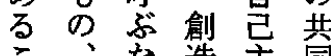
こな造主同

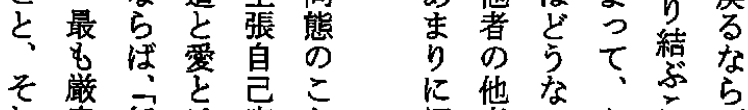

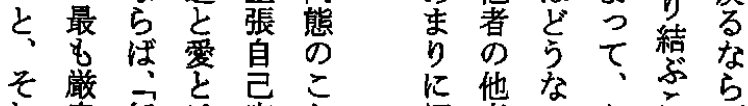

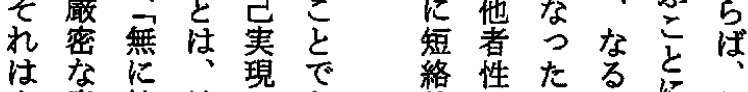

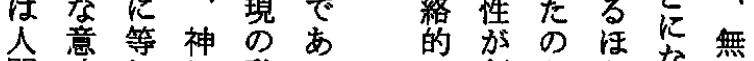

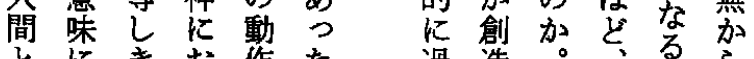

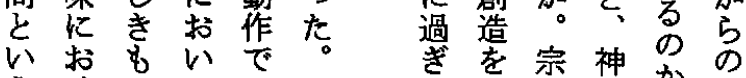

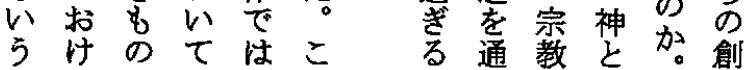




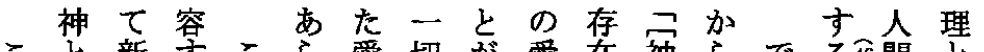

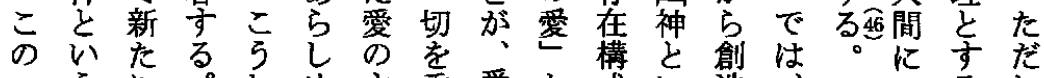

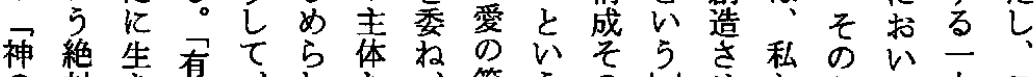

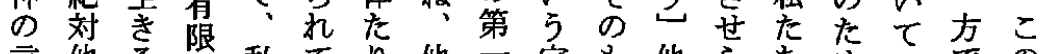

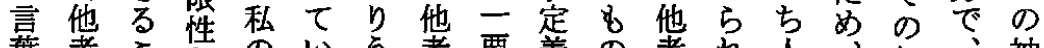

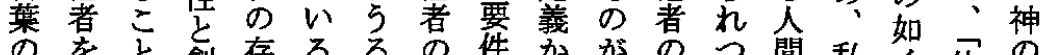

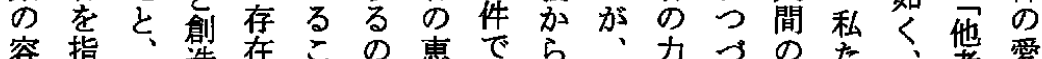

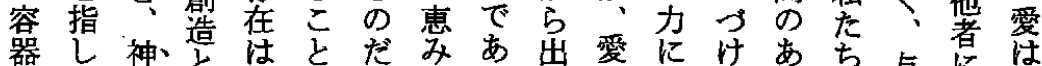

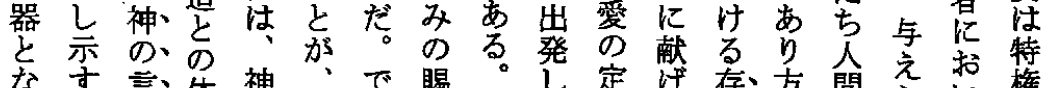

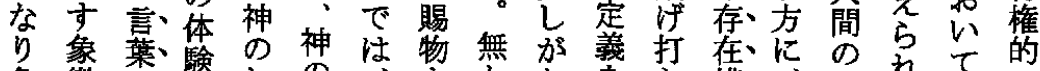

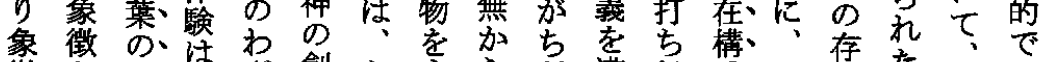

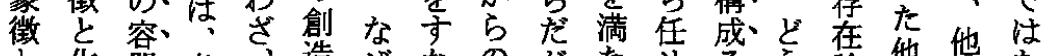
と化器虚、造ぜなの加たせを、う論倭者あ な高に、無神の方拉創、し

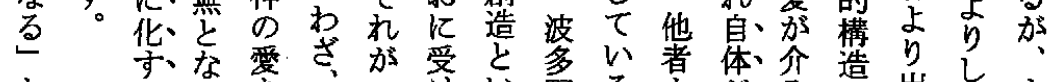

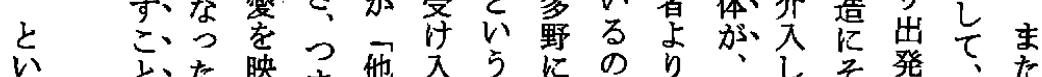

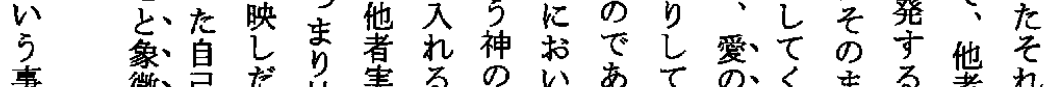

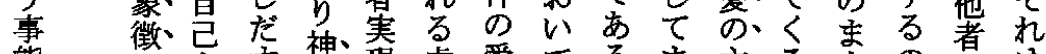

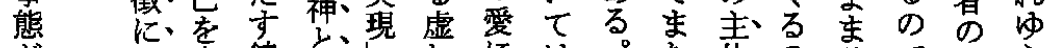

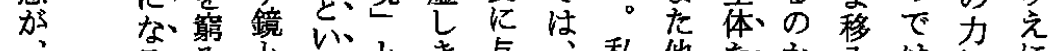
人 る、みな な

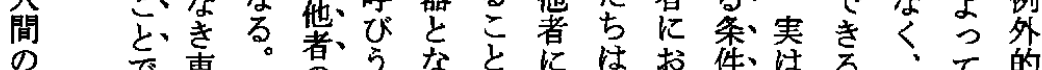

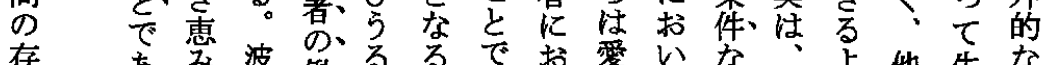

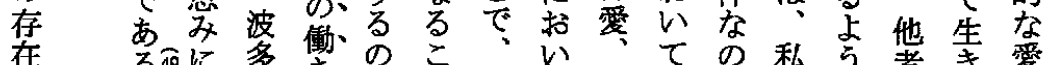

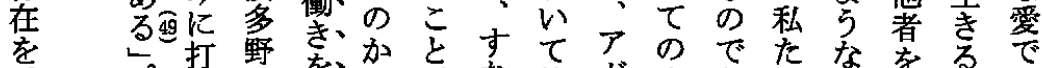

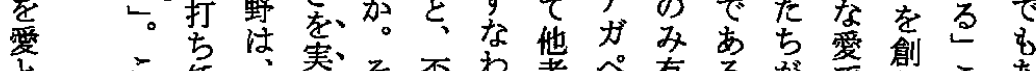

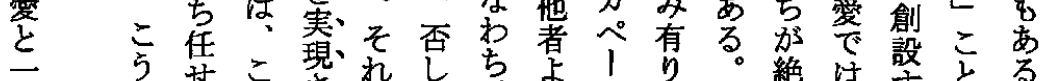
致 し せ

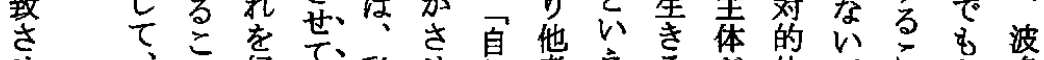

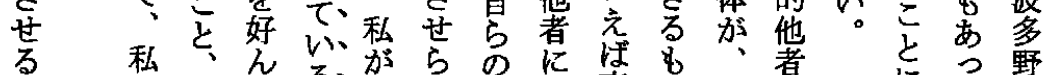

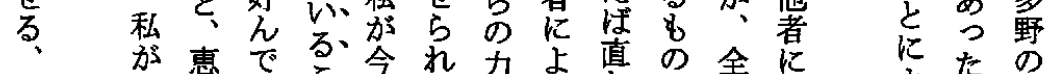

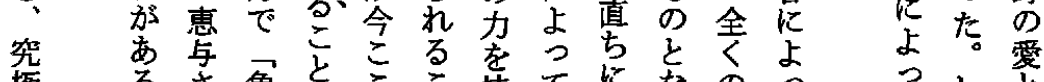

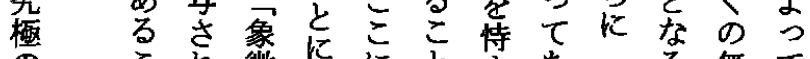

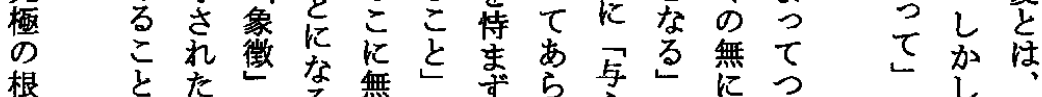
根 そ た

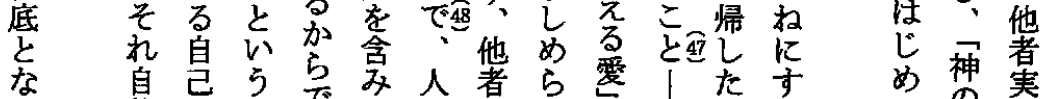

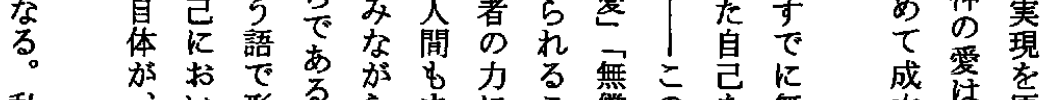
私 趾成愛原 


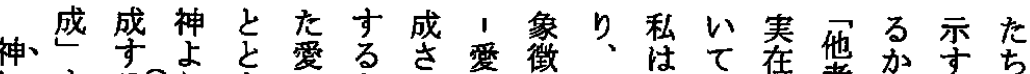

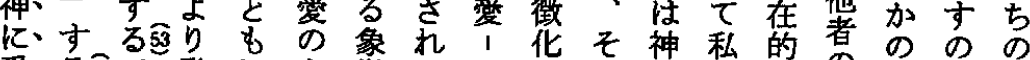

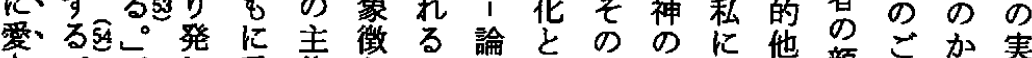

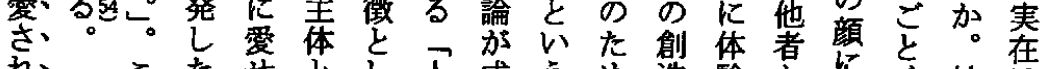

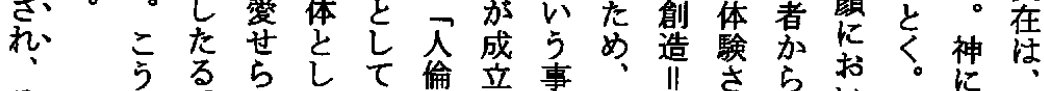

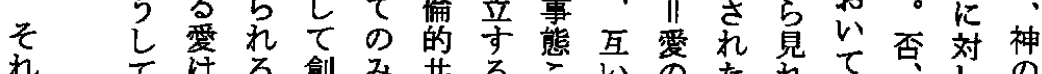

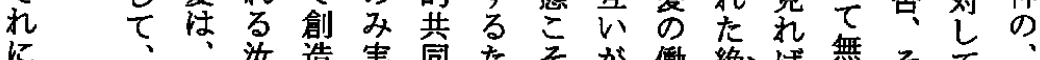
に、、汝造塞同たそが㗢絶は無そてて

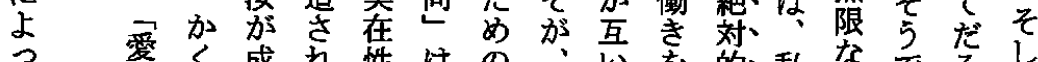

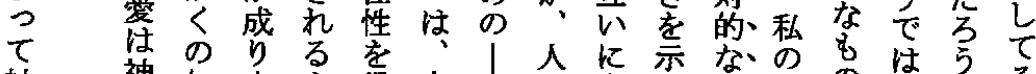

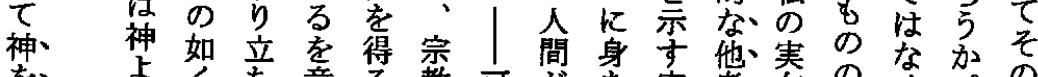

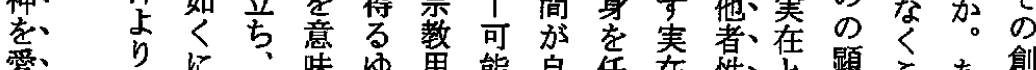

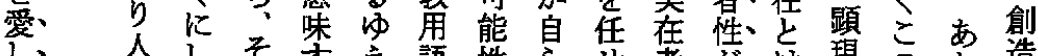

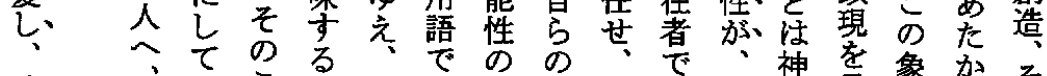
そ 次、它。実表条存互市人神貝象徽を

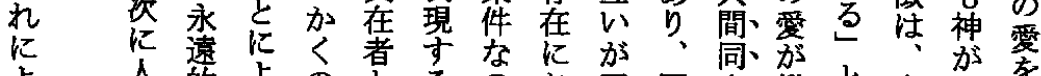

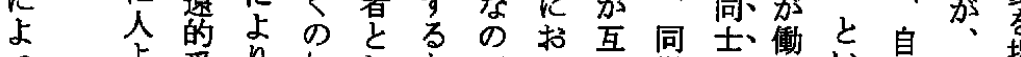

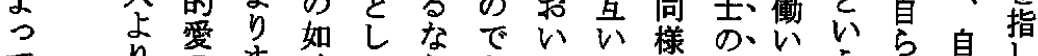

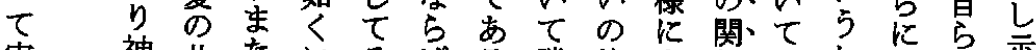

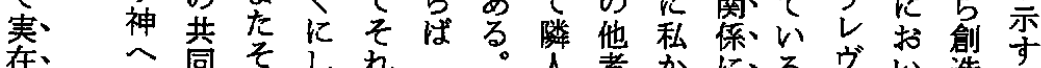

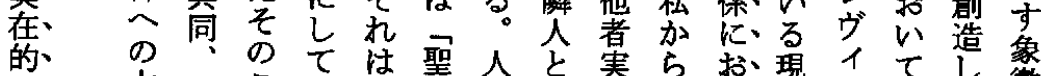

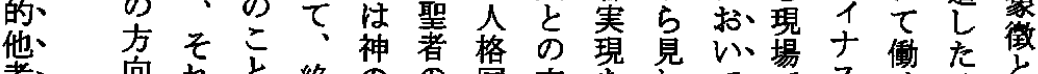

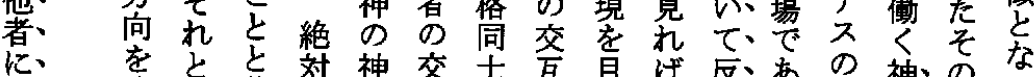

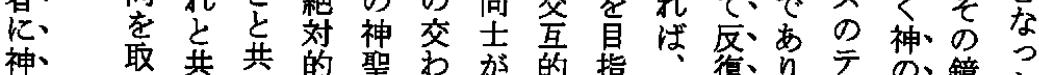

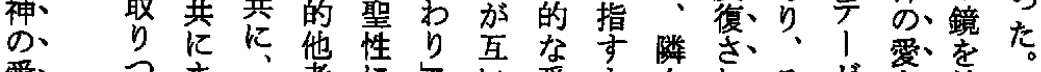

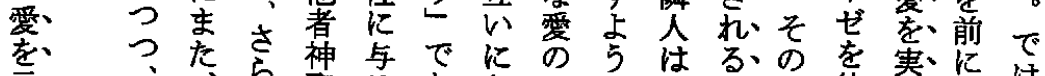

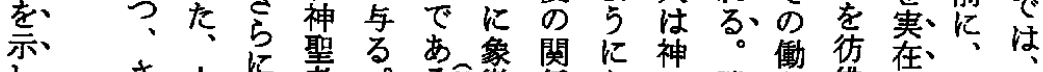

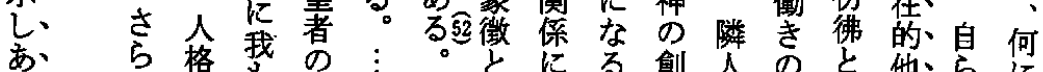

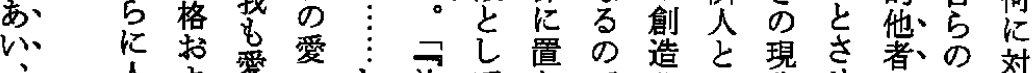

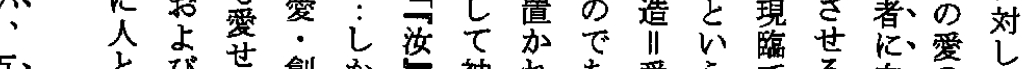

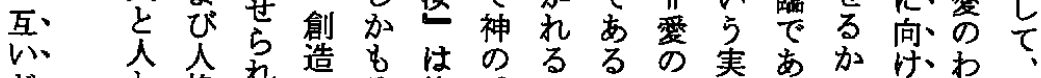

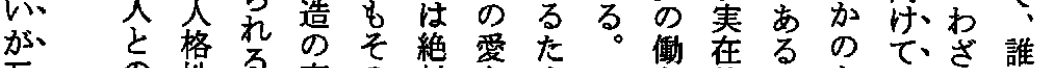

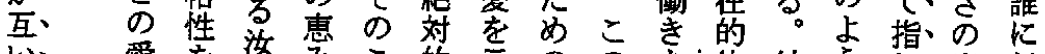

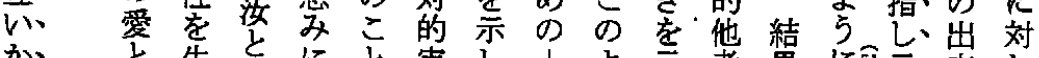

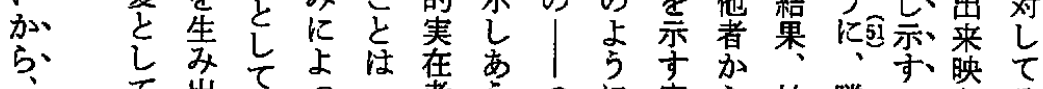

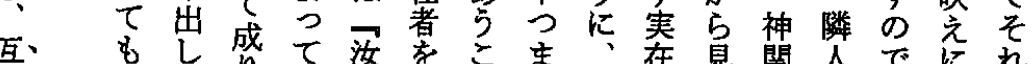

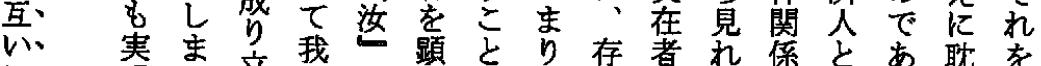

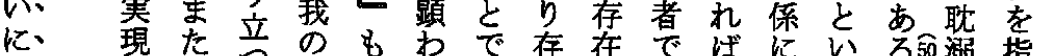

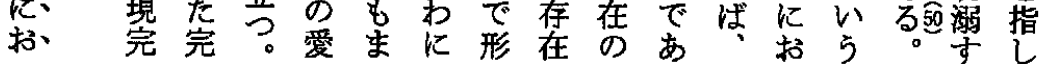


乙無以

加方上

? 創現

湯他造傯

浅者と宗

に害公教

よ現 5 哲

○概学

て指菍掠

摘のそけ

さ の る

兑愛宗存

い樂学

よ皇学

万合決論

行臨定の

せ的展

こる な

愛と点

の顼据

同能充

加にこ加

らなとら

いた 加波

なの?野

るでて の

倫省思

理る。私想

道占捉

加存充

立在な

占態管

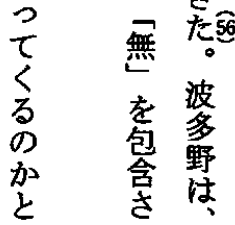

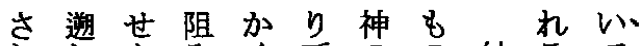

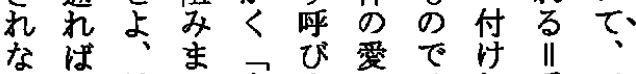

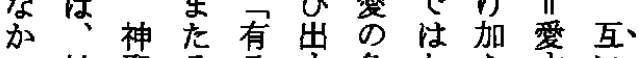
つ神聖そる壬象なえ守い 結たと者れ創徽い。晶るに、

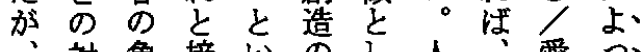
自話徽触 5 恵て間無䨓て、

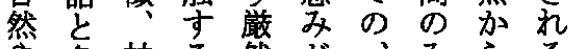
や名神る然が、みらる 無、 文づのこ全物なの等 花け言とる方。ら創のら、

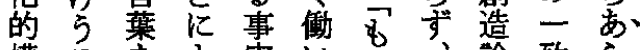
構る老よ実いし、論致ら、 筑で伝つ注て之存加をし、

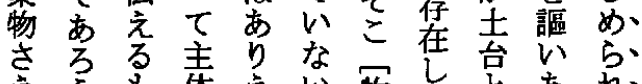

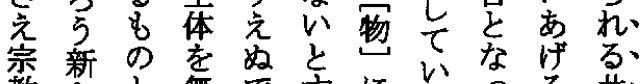
教たと無で恋にるつる 晎 哲ななにあれあるての同

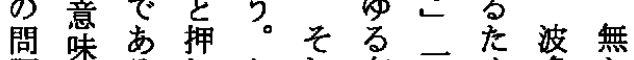
題を等方势存切め多加

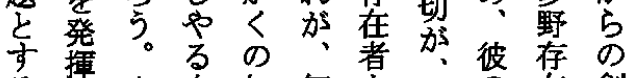
る势 自如何索神分在創 ある゙か然にで悲神存 1 造 るあく他しる在愛在出 種方著て吕の創愛論発 の 可如の、ま中創告で点

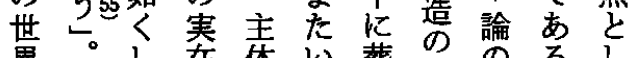
論残て在体思蕉わ加る。 の念物注前にな空程

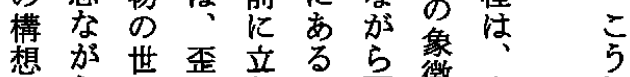

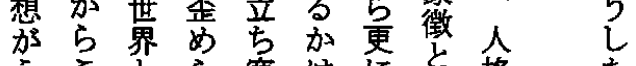

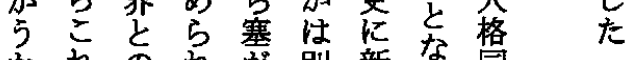

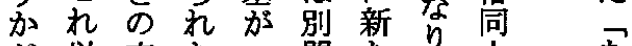
加以交たっ問たり声市

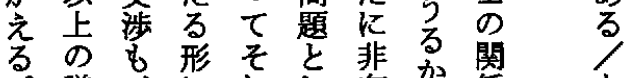
議、にれ亡存驾俰等

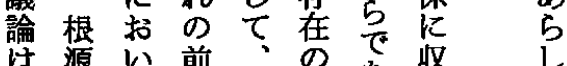

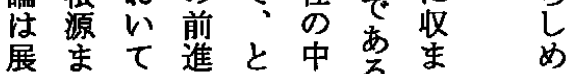

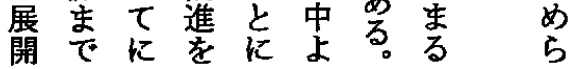


I - $^{*}$ 註

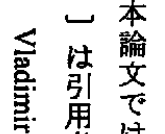

霫住

謇品波

等.

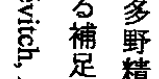

筑粠

劦金

要

西波

書

尤

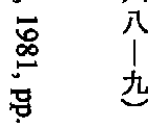

加

紊要

邦 引

银 䍿

膳適

琶琵

仲仮

準遣

䇥息

笫改

み妨

李 た

畫客 た

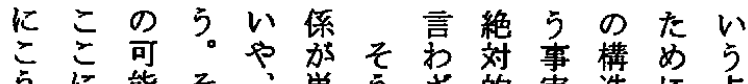

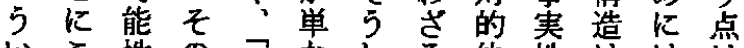
いこ性の愛なしる他性はは壮 ううに思觉るたを者の説: 不 問し開想な事難えのみ得実明 いてか住る実点な他加的在な だ存れ、語では、要強で的ま 在る現加は市。性調あ他主 たしの代となる茂さる者で のてでのらくに含れのののあ

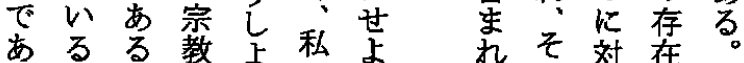

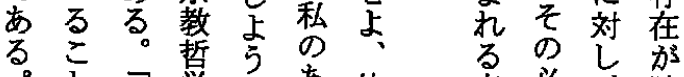

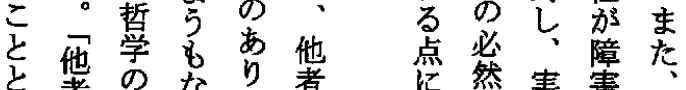
々、者のな省学然害害 何沙齐方東方只的在官そ 吕な脈陳根関扰他る以 必照䉓底倸 然敬ら聞に根を ならてこ的等同 関き梁尔同

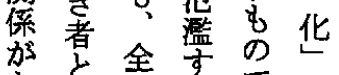
要全食客飞 焉感穷念要無

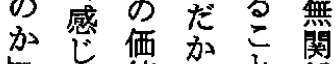

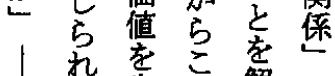

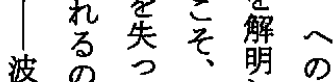
桨名大乞籍 野分食忽

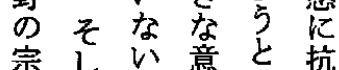

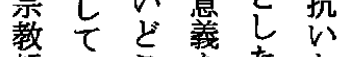
帮、气原な 学々方有波加 問占架叠惫 問在む公累 の感しる思率

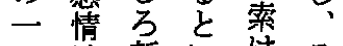

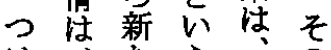

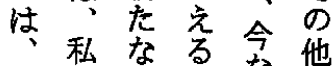

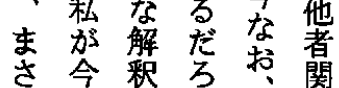

蛙著占

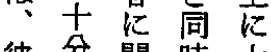
彼分関時大 のにしに 高考七不な 次祭注可間 のさ題 実夰表无解 在て体品要 美兮经学名。 然华姜す 前住量䪙 提言離等纪 等线望る。見 龙算先主 当独证占 及特证纪 で贻立举波 考它てた野 祭展甠时 筂集存間

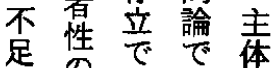
是合要积 七床机存 支点众过章 の。例飞

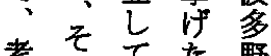


5 $\frac{4}{4}$

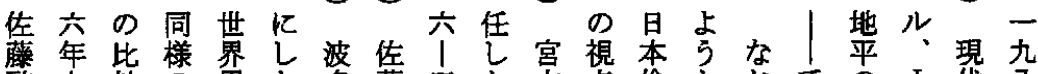

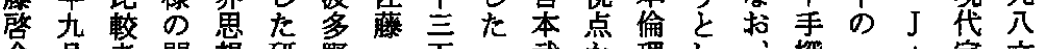
介月考問想研野吾二武加理し人染二1宗六。

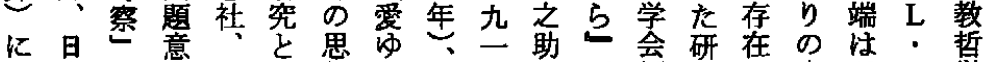

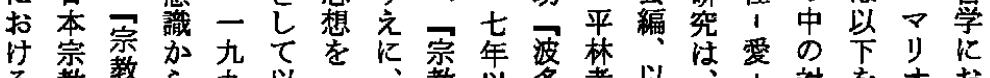

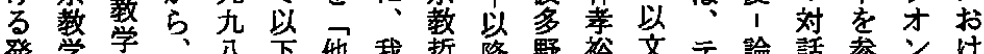
發学学、留他我哲降野裕齐テ論話参ン け 表会研波。を者在学の精編社、と照、る 加第究多他参論 り 基宍害野著照心 に吾䌂と論。と前出注日西九七榮藤占、 な回要々と片し前版は本学入を安管了需

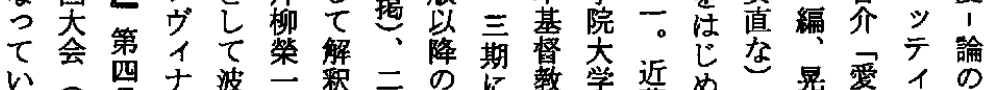

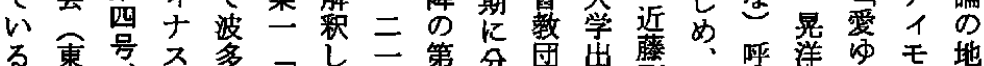
る東号不多展第分団出滕、呼洋市地 北京比野時九严出版剛こ称畫え平

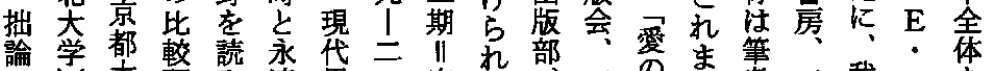

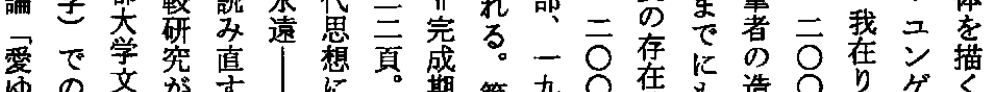

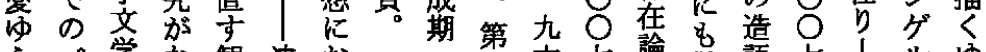

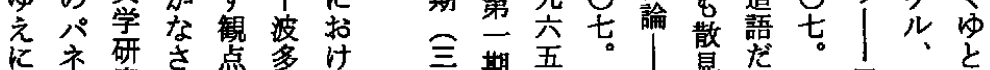

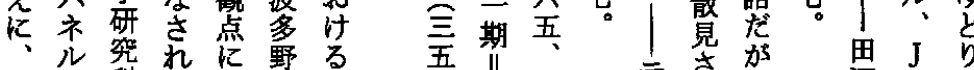

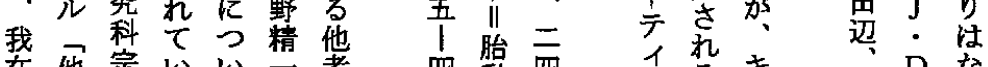

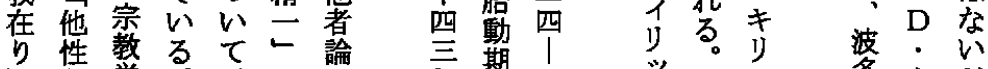

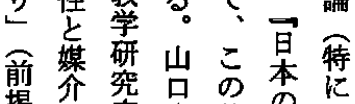

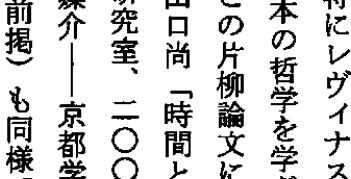

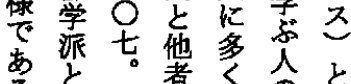
る

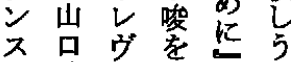
哲論イ受常る

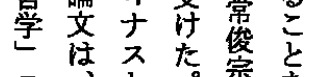
企二波ま害郎

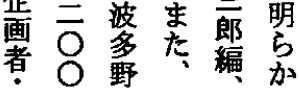


11

10

9 8

$\widehat{7} \widehat{6}$

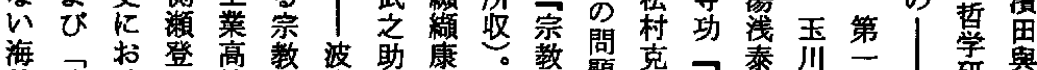

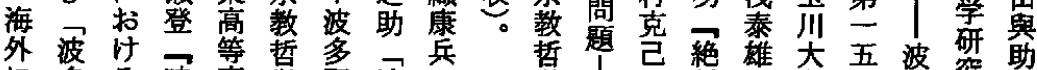

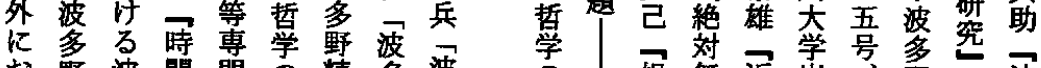
お野波間門の精多波等 $\mathrm{P}$ 根無近出多野第波 け精多之学方二野多根? 源背代版東精第多

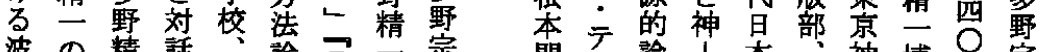

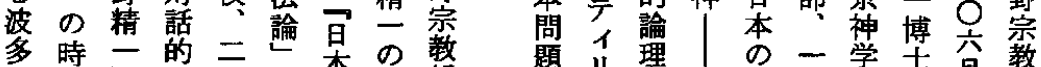

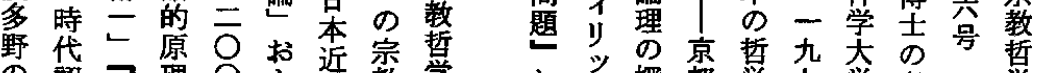

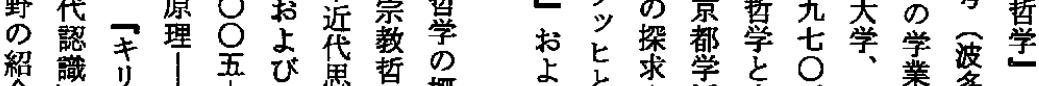

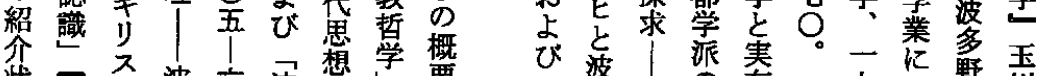

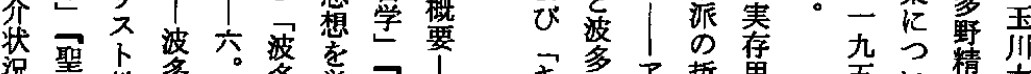

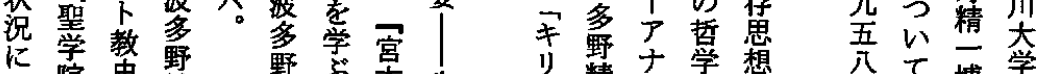
に院史野野学生少晴ナ学想公こ博学 い学学精 精人武の全こギ春創宾岩遍版

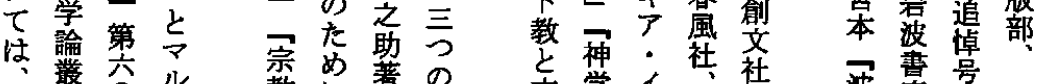

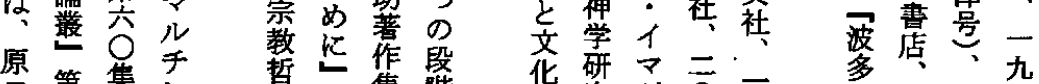
品第集

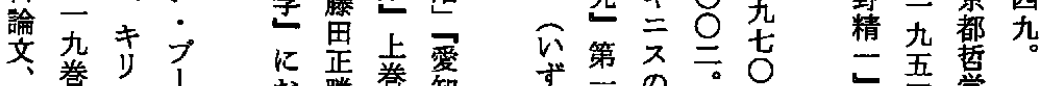

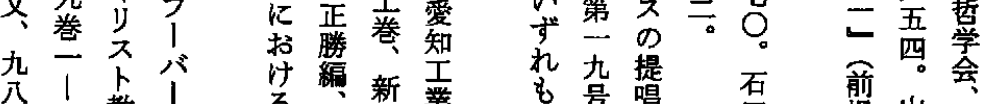

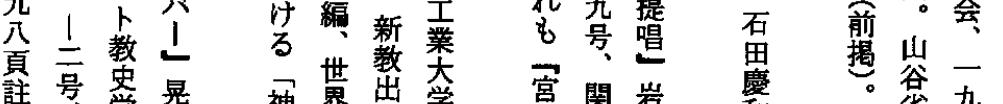

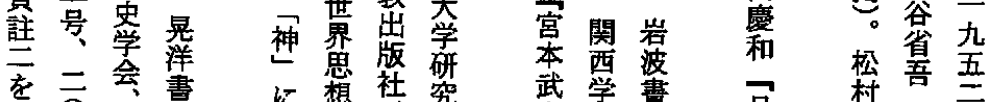

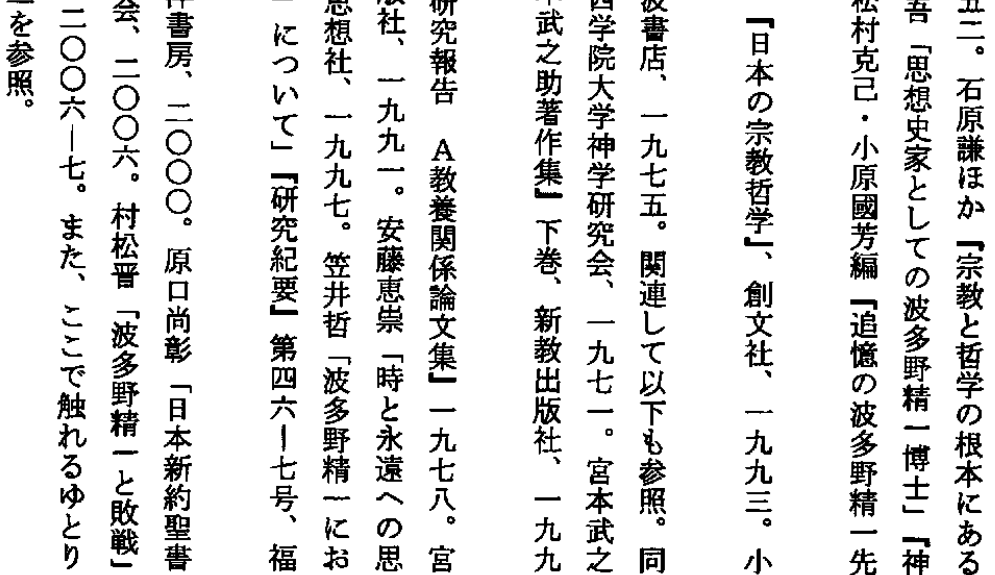




\section{6 $25 \widehat{25} \widehat{23} \widehat{22} \widehat{21} \widehat{20}$}

$\widehat{19}$

$\widehat{18} \widehat{17} \widehat{16} \widehat{15} \widehat{14} \widehat{13} \widehat{12}$

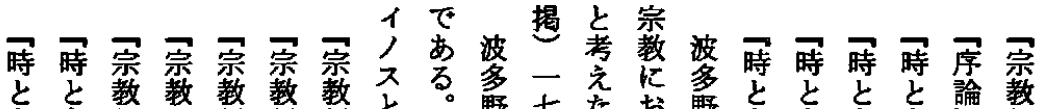

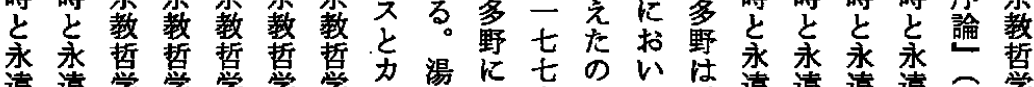
遠遠学学学学学兮湯に括加て遠遠遠遠学

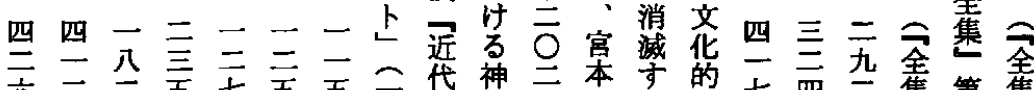

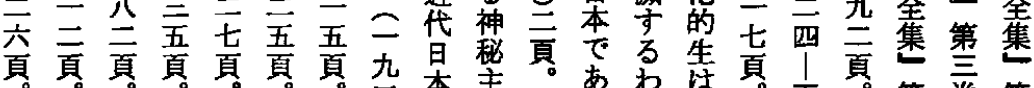
強

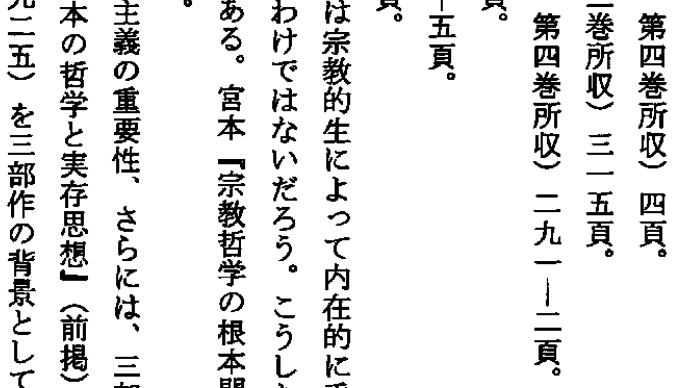

解問唐

解 九作題点

二成等越

頁 立

$\frown$ 下条

の湯 集

解

は江て

極 5 神

㓡

党

秘

前占え

题宗品

特䓔 る

に交生き

入斿

讨考

亲る党

頁文花加

点研的

か究宲側だ

ら、の本面妿

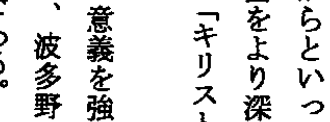

調諭孝?

文亭察花

Э告货华花

号湦前唯妿 
$\widehat{37} \widehat{36}$

$\widehat{35} \widehat{34} \widehat{33} \widehat{32} \widehat{31} \widehat{30}$

29 $\widehat{28} 27$

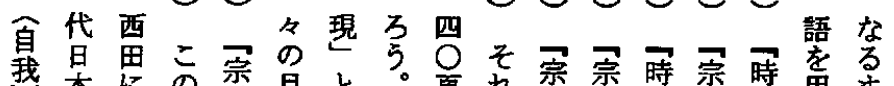

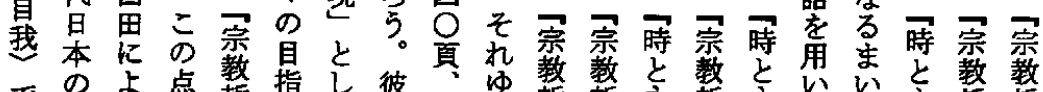

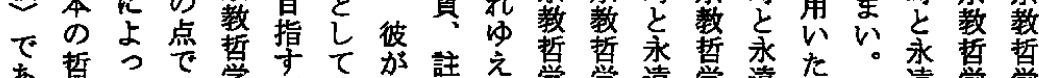
あ哲っで学学て 作聖註え学学遠学遠た波遠学学

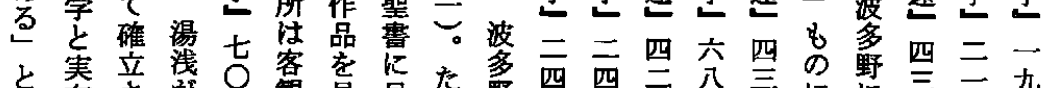

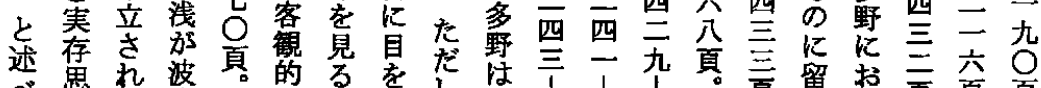

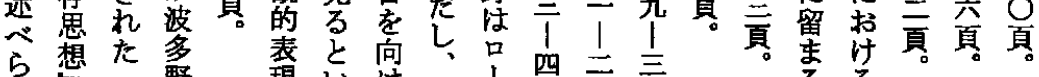

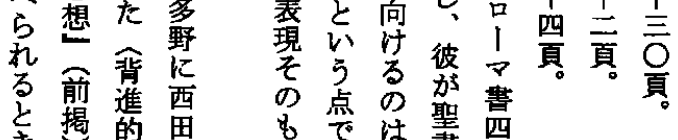

き掲的田

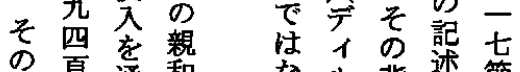

評頁通和委性背述節

にしで

は加の見

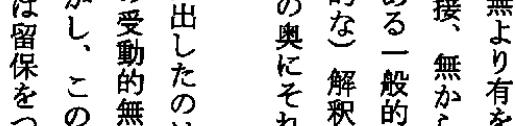

留し、受出

け文限は标积的占学

さに拡步源的験創び

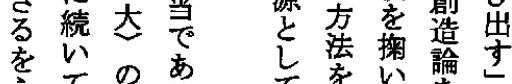

なて 思う

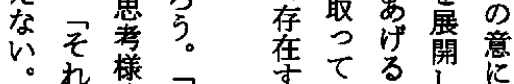

波は式波劣いてた解

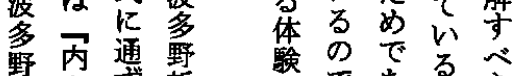

にをず哲毞であるす

打みる学あある。゙

いるこにるる。注あ

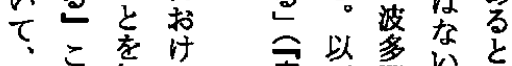

自亡知る 序卡野点言

己にり得自論の恕点

萛っ得峩 三節体留時

己て無湯 構 士 参験意

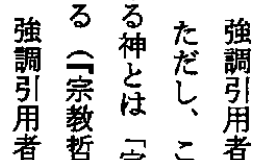

お先浅造 頁照自心遠

者授宗こ者。

五的 厄゙

吾体

椋䧇

下 必

主率

封

施

対 聖

的

な 㓥

守 述

8 を

の 前

老提

言 と

表て

等

たな

め) W

便

宜 強

上 調

神

一拈

と加

いね

5 ぱ 


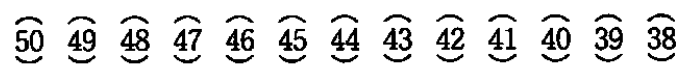

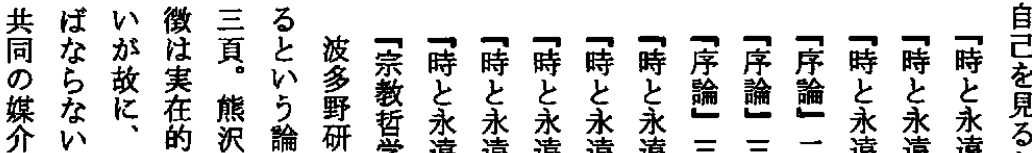
的以言他義理究学遠遠遠遠遠三三方遠遠遠 な濱葉者宣構に二四四四四四分四九四四四々 根留の

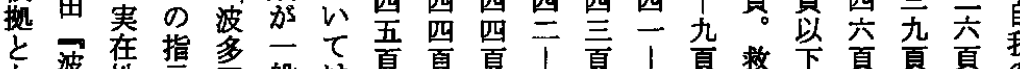

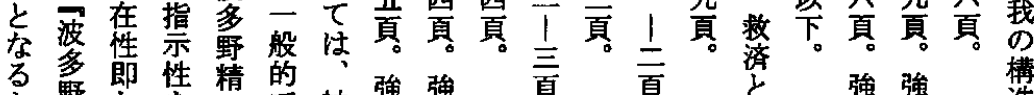

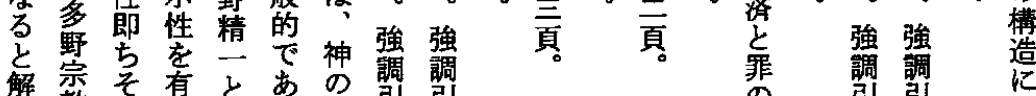

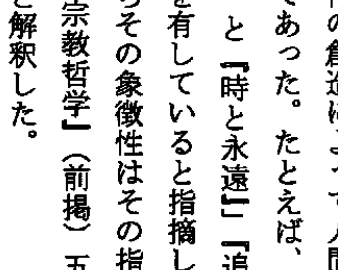

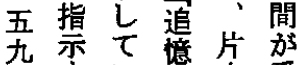
九すい出山愛

頁 るる。波正 の

強在象多野主本

調的徽精体弃

原著洗先员 。年象生宗そ

本内加笅の

論面担前哲結

は連そ—学

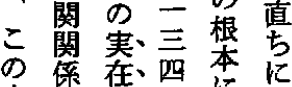

実㷛泉的頁少

在中他劣間

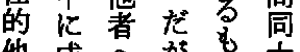

售盛 加告志

人表指濱愛

のる宗田前の

指々性は揭共

閶 埇埇

閣檞捅者

示言 $k$ 的 同

性 わ他確一 が

かななに二成

愛讨な象立

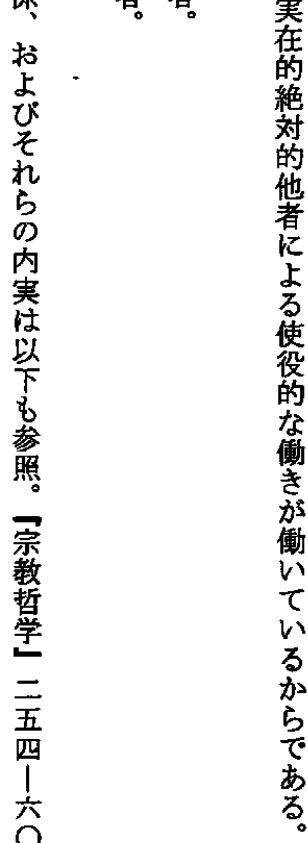




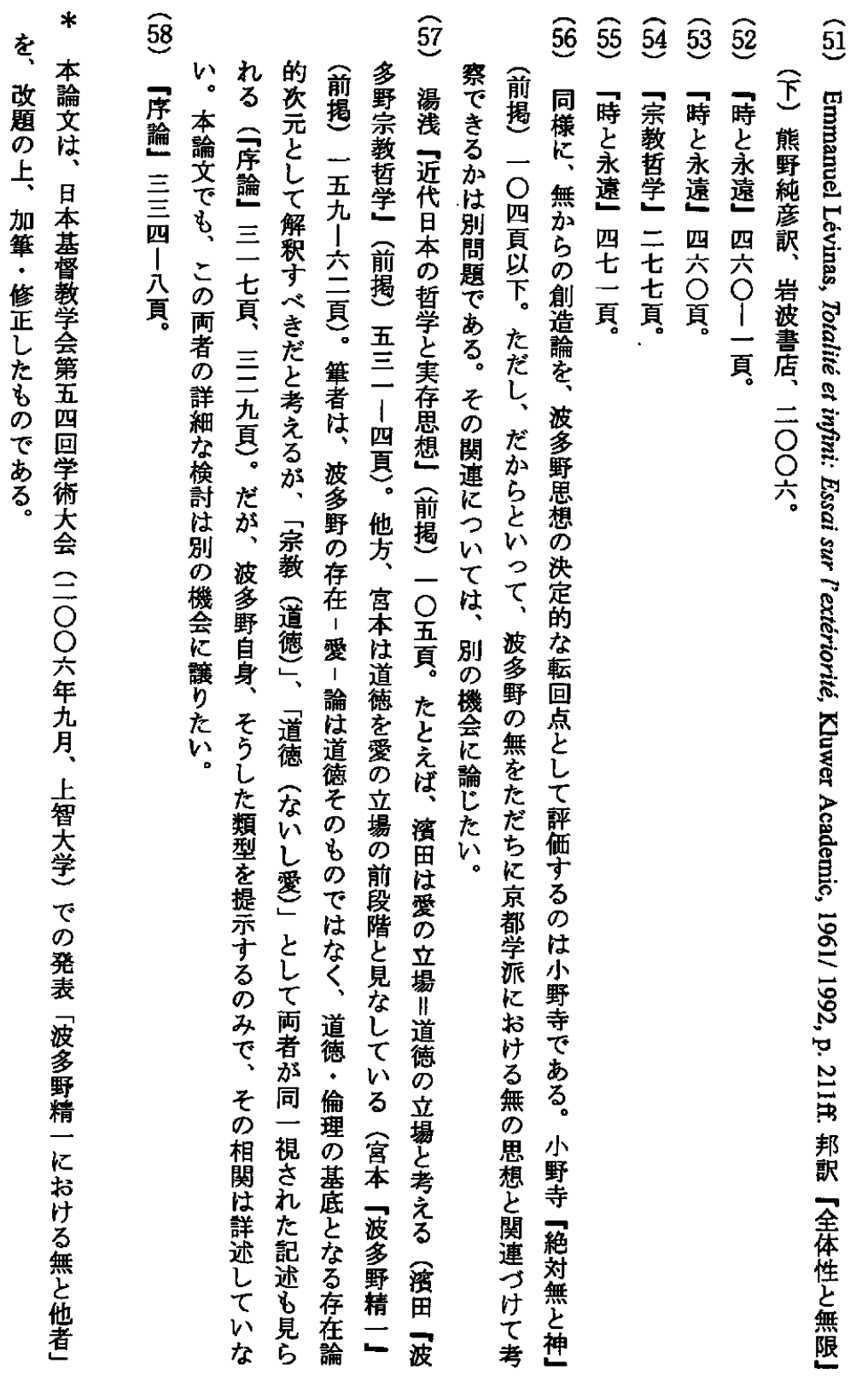

